\title{
Methane emissions associated with the conversion of marshland to cropland and climate change on the Sanjiang Plain of northeast China from 1950 to 2100
}

\author{
T. $\mathbf{L i}^{1}$, Y. Huang ${ }^{2}$, W. Zhang ${ }^{1}$, and Y.-Q. Yu ${ }^{1}$ \\ ${ }^{1}$ State Key Laboratory of Atmospheric Boundary Layer Physics and Atmospheric Chemistry, Institute of Atmospheric \\ Physics, Chinese Academy of Sciences, Beijing 100029, China \\ ${ }^{2}$ The State Key Laboratory of Vegetation and Environmental Change, Institute of Botany, Chinese Academy of Sciences, \\ Beijing 100093, China
}

Correspondence to: W. Zhang (zhw@mail.iap.ac.cn)

Received: 17 March 2012 - Published in Biogeosciences Discuss.: 24 May 2012

Revised: 7 November 2012 - Accepted: 21 November 2012 - Published: 18 December 2012

\begin{abstract}
Wetland loss and climate change are known to alter regional and global methane $\left(\mathrm{CH}_{4}\right)$ budgets. Over the last six decades, an extensive area of marshland has been converted to cropland on the Sanjiang Plain in northeast China, and a significant increase in air temperature has also been observed there, while the impacts on regional $\mathrm{CH}_{4}$ budgets remain uncertain. Through model simulation, we estimated the changes in $\mathrm{CH}_{4}$ emissions associated with the conversion of marshland to cropland and climate change in this area. Model simulations indicated a significant reduction of $1.1 \mathrm{Tg} \mathrm{yr}^{-1}\left(0.7-1.8 \mathrm{Tg} \mathrm{yr}^{-1}\right)$ from the 1950 s to the 2000s in regional $\mathrm{CH}_{4}$ emissions. The cumulative reduction of $\mathrm{CH}_{4}$ from 1960 to 2009 was estimated to be $\sim 36 \mathrm{Tg}$ (24$57 \mathrm{Tg}$ ) relative to the 1950s, and marshland conversion and the climate contributed $86 \%$ and $14 \%$ of this change, respectively. Interannual variation in precipitation (linear trend with $P>0.2$ ) contributed to yearly fluctuations in $\mathrm{CH}_{4}$ emissions, but the relatively lower amount of precipitation over the period 1960-2009 $\left(47 \mathrm{~mm} \mathrm{yr}^{-1}\right.$ lower on average than in the 1950 s) contributed $\sim 91 \%$ of the reduction in the areaweighted $\mathrm{CH}_{4}$ flux. Global warming at a rate of $0.3^{\circ}$ per decade $(P<0.001)$ has increased $\mathrm{CH}_{4}$ emissions significantly since the 1990s. Relative to the mean of the 1950s, the warming-induced increase in the $\mathrm{CH}_{4}$ flux has averaged $19 \mathrm{~kg} \mathrm{ha}^{-1} \mathrm{yr}^{-1}$ over the last two decades. In the RCP (Representative Concentration Pathway) 2.6, RCP 4.5, RCP 6.0 and RCP 8.5 scenarios of the fifth IPCC assessment report (AR5), the $\mathrm{CH}_{4}$ fluxes are predicted to increase by $36 \%$,
\end{abstract}

$52 \%, 78 \%$ and $95 \%$, respectively, by the 2080s compared to 1961-1990 in response to climate warming and wetting.

\section{Introduction}

Methane $\left(\mathrm{CH}_{4}\right)$ is recognized as one of the most potent greenhouse gases; it is 25 times more powerful than carbon dioxide $\left(\mathrm{CO}_{2}\right)$ in terms of its global warming potential (IPCC, 2007). Although natural wetlands cover only 5-8\% of the Earth's land surface area (Ramsar Convention Secretariat, 2004; Mitsch and Gosselink, 2007), they contribute 20-25\% of the total annual $\mathrm{CH}_{4}$ emissions (IPCC, 2007; Mitsch and Gosselink, 2007).

The regional and global $\mathrm{CH}_{4}$ budgets of wetlands are influenced by large-scale processes, such as the conversion of wetlands to other uses (Bridgham et al., 2006; Huang et al., 2010) and climate change (Cao et al., 1998; Gedney et al., 2004; Shindell et al., 2004). Half of the world's wetlands were lost during the 20th century (Revenga et al., 2000). In China, approximately $20 \%$ of the wetlands were lost from 1950 to 2000 , and $82 \%$ of the loss has been attributed to agricultural use (An et al., 2007). Climate change, particularly in terms of temperature (Charmann and Hendon, 2000) and precipitation (Cao et al., 1998; Charmann and Hendon, 2000; Vepraskas and Caldwell, 2008), alters the biochemical processes involved in $\mathrm{CH}_{4}$ production, oxidation and emission (Strack et al., 2008; Updegraff et al., 2001). 


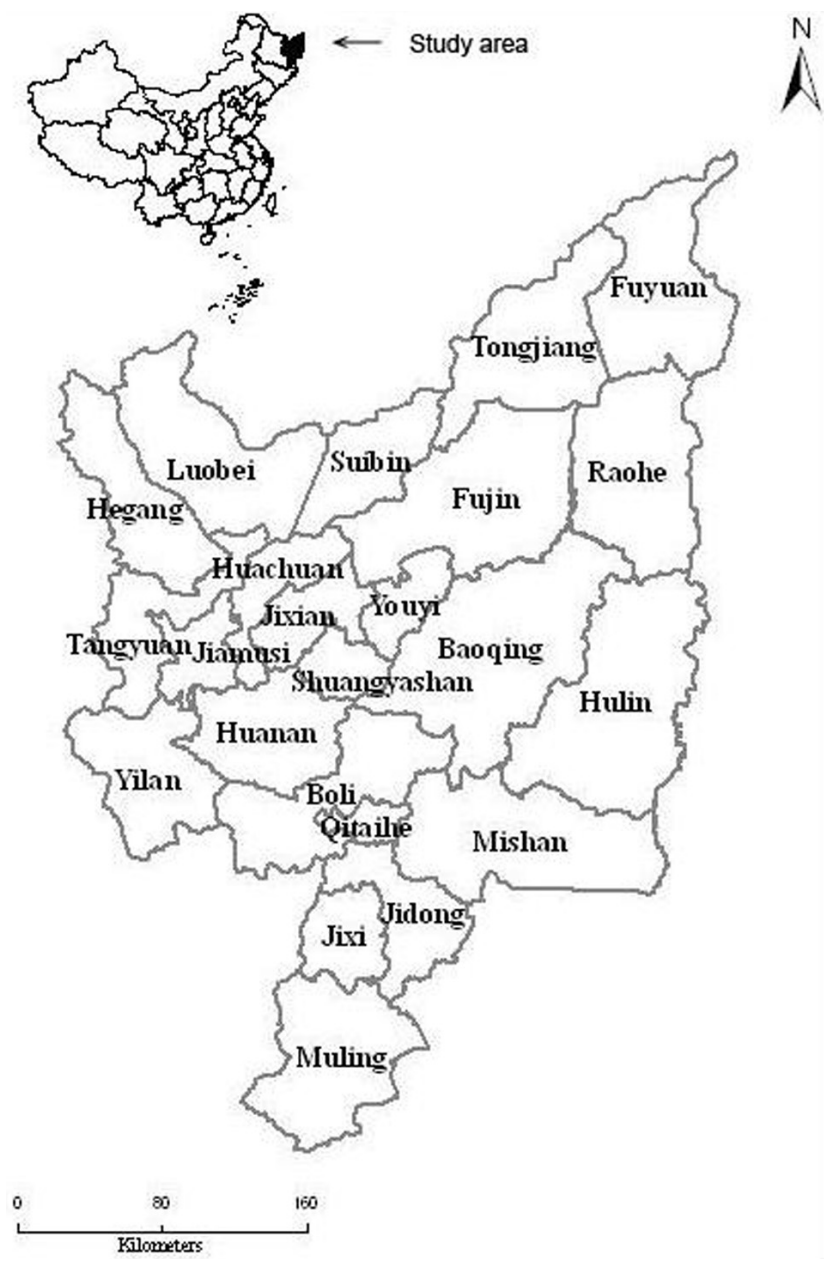

Fig. 1. The study area on the Sanjiang Plain of northeast China, covering 23 counties and 3 administrative farms.

The Sanjiang Plain, located in northeast China, was formerly the largest marshland complex in China (Huang et al., 2010; Wang et al., 2006). In the 1950s, the wetland area of the Sanjiang Plain (Liu and Ma, 2000) accounted for $\sim 70 \%$ of Heilongjiang province and $\sim 40 \%$ of northeast China (Ning et al., 2008). However, an extensive area of marshland has been converted to cropland over the last six decades in this region (Liu and Ma, 2000; Zhang et al., 2003; Huang et al., 2010). Meanwhile, a significant increase in the surface air temperature has been detected (Ding and Cai, 2007), occurring at a rate of $0.3^{\circ}$ per decade, and annual precipitation declined at a rate of $15 \mathrm{~mm}$ per decade from 1950 to 2000 in northeast China (Zhao et al., 2009). Furthermore, significant warming has been predicted to occur under different scenarios by the end of the 21 st century (SRES A2, B2 for IPCC AR4 and RCPs for IPCC AR5; Editorial Committee of China's National Assessment Report on Climate Change, 2007; Bernie, 2010). By 2100, the temperature is projected to increase by $4.5^{\circ}$ or $6.1^{\circ}$, while precipitation will increase by $12 \%$ or $13 \%$ in northeast China under the SRES B2 and A2 scenarios, respectively (Editorial Committee of China's National Assessment Report on Climate Change, 2007).

Researchers have attempted to understand the effects of temperature and precipitation on seasonal variation in $\mathrm{CH}_{4}$ fluxes in site-specific studies (Yang et al., 2006a; Song et al., 2009) to estimate regional $\mathrm{CH}_{4}$ emissions by extrapolating field measurements to the region (Cui, 1997; Ding et al., 2004; Ding and Cai, 2007) and to quantify regional $\mathrm{CH}_{4}$ emissions associated with marshland conversion on the Sanjiang Plain (Huang et al., 2010), whereas less attention has been given to an integrated evaluation of $\mathrm{CH}_{4}$ emissions in relation to marshland conversion and climate change.

Recognizing the significance of wetlands in regional $\mathrm{CH}_{4}$ budgets, this study focuses on quantifying the variation in $\mathrm{CH}_{4}$ emissions on the Sanjiang Plain of northeast China via model simulations. The objectives of this study are to estimate the change in regional $\mathrm{CH}_{4}$ emissions associated with the conversion of marshland to cropland and climate change and to identify the contributions of the conversion of marshland to cropland and climatic factors to the changes in $\mathrm{CH}_{4}$ emissions over the period of 1950-2009. We also make predictions regarding the impact of climate change on the $\mathrm{CH}_{4}$ flux from the marshland extending to the year 2100 .

\section{Materials and methods}

\subsection{Research area}

The research area lies on the Sanjiang Plain, situated in the eastern part of Heilongiiang Province, northeast China (Fig. 1). It is located between $43^{\circ} 50^{\prime} \mathrm{N}$ and $48^{\circ} 28^{\prime} \mathrm{N}$ latitudinally and between $129^{\circ} 11^{\prime} \mathrm{E}$ and $135^{\circ} 05^{\prime} \mathrm{E}$ longitudinally, with a total area of 11.89 million ha (Zhang et al., 2006) covering 23 counties and 3 administrative farms (see supplementary material A for more details).

The study area is characterized by a temperate humid and subhumid continental monsoon climate with an annual mean temperature of $\sim 2.5^{\circ}$. Annual rainfall ranges from 350 to $770 \mathrm{~mm}$, with $80 \%$ occurring from May to September. The freshwater marsh is mainly dominated by Carex plants and Deyeuxia angustifolia, which generally begin growing in late May and senesce in late September. The aboveground biomass ranges from 260 to $700 \mathrm{~g} \mathrm{~m}^{-2}$ (Guo et al., 2008; Hao, 2006; He, 2001; Ni, 1996; Wang et al., 1993; Yang et al., 2002; Yang et al., 2006b; Zhou et al., 2006; Zhou et al., 2009; Zhang et al., 2007).

After marshland conversion, the cropland became the dominant landscape on the Sanjiang Plain (Zhang et al., 2010). By now, the main species of crops on the Sanjiang Plain are soybean, corn and rice (Heilongjiang Provencal Bureau of Statistics, 2010). Irrigated rice is harvested once per year. The rice growing season is generally from May to September. The average grain yield of rice over the period of 
2000-2009 was $6.4 \mathrm{tha}^{-1}$ (Heilongjiang Provencal Bureau of Statistics, 2010).

\subsection{The modeling approach}

Two biogeophysical models, CH4MOD and

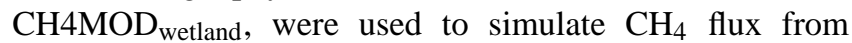
an area of irrigated rice cultivation and a natural marshland, respectively. Both models have the potential for scaling up because they have been validated with field observations from various types of rice paddies and natural wetlands, respectively. To quantify the individual factorial impact on $\mathrm{CH}_{4}$ fluxes from marshland, we performed several simulation experiments using $\mathrm{CH} 4 \mathrm{MOD}_{\text {wetland }}$.

\subsubsection{CH4MOD for irrigated rice cultivation}

CH4MOD was developed to predict methane fluxes from rice paddy soils. The model associated this process with rice growth, organic $\mathrm{C}$ depletion and environmental factors (Huang et al., 2004). The model's input parameters included the rice grain yield, the soil sand percentage, the amount of organic amendment, the water management pattern, and the daily air temperature. The outputs are the daily and annual rates of $\mathrm{CH}_{4}$ production and emissions. The model was validated against a total of 94 field observations that covered the main rice cultivation regions from northern (Beijing, 40 $30^{\circ} \mathrm{N}, 116^{\circ} 25^{\prime} \mathrm{E}$ ) to southern (Guangzhou, $23^{\circ} 08^{\prime} \mathrm{N}, 113^{\circ} 20^{\prime} \mathrm{E}$ ) China and from eastern (Hangzhou, $30^{\circ} 19^{\prime} \mathrm{N}, 120^{\circ} 12^{\prime} \mathrm{E}$ ) to southwestern (Tuzu, $\left.29^{\circ} 40^{\prime} \mathrm{N}, 103^{\circ} 50^{\prime} \mathrm{E}\right)$ China. This model can reasonably simulate $\mathrm{CH}_{4}$ flux from irrigated rice fields (Huang et al., 2004).

In the rice paddy, after conversion from marshlands, we used $\mathrm{CH} 4 \mathrm{MOD}$ to simulate $\mathrm{CH}_{4}$ fluxes from the rice paddy of the Sanjiang Plain. We paid major attention to the impacts of human activities on $\mathrm{CH}_{4}$ emission. The main agriculture practices involving methane processes in rice paddies include organic matter amendment, irrigation and harvesting. In CH4MOD, decomposition of the added organic matter (such as rice straw or green manure) was thought to be part of the predominant source of methanogenic substrates (Huang et al., 2004). But substrates derived from the decomposition of soil organic matter contributed little in comparison to the fresh carbon and is not considered in CH4MOD (Huang et al., 2004). Irrigation strongly influenced the water fluctuation, which was one of the most sensitive environmental factors to $\mathrm{CH}_{4}$ flux (Boon et al., 1997; Ding et al., 2002). In CH4MOD, we cataloged five patterns of water management for rice cultivation in China. The intermittent flooding as well as intermittent irrigation was used to control the water level for single rice in northern China (Huang et al., 2004).

\subsubsection{CH4MOD $_{\text {wetland }}$ for natural wetlands}

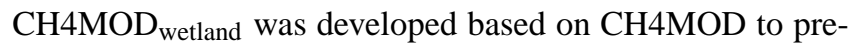
dict $\mathrm{CH}_{4}$ flux from natural wetland ( $\mathrm{Li}$ et al., 2010). The model adopted the rationale of CH4MOD and focused on the supply of methanogenic substrates in natural wetlands that differs significantly from that in rice paddy. The input variables included environmental variables, soil properties and plant growth-related controls. The outputs were the daily and annual rates of $\mathrm{CH}_{4}$ production and emissions. $\mathrm{CH} 4 \mathrm{MOD}_{\text {wetland }}$ was validated against independent field measurements of $\mathrm{CH}_{4}$ fluxes from different wetland sites, including a marshland on the Sanjiang Plain (northeast China), a peatland on the Ruoergan Plateau (southwest China), a fen in Saskatchewan (Canada) and bogs in Michigan (USA). Model validation showed that $\mathrm{CH}_{4} \mathrm{MOD}_{\text {wetland }}$ was generally capable of simulating the seasonal and interannual variations in $\mathrm{CH}_{4}$ fluxes from different sites, especially in northeast China (Li et al., 2010).

Before cultivation, we used $\mathrm{CH} 4 \mathrm{MOD}_{\text {wetland }}$ to simulate $\mathrm{CH}_{4}$ fluxes from the marshland of the Sanjiang Plain. In comparison with CH4MOD, we paid more attention in the natural processes of plant growth and water table fluctuation, as well as the decomposition of soil organic matter ( $\mathrm{Li}$ et al., 2010 ) in $\mathrm{CH}_{4} \mathrm{MOD}_{\text {wetland. }}$. Unlike in rice paddies, plants in marshlands are not harvested at the end of the growing season. The decomposition of plant litter supplies substrates for methanogens. Besides, marshland ecosystems accumulate great amounts of organic matter in a thick sod layer (Bertness, 1988; Frolking et al., 2001; Gorham et al., 2003; Zhang et al., 2008) that also becomes a source of methanogenic substrates. We paid special attention to the substrates derived from the decomposition of above- and belowground plant litter and soil organic matter in the CH4MOD wetland ( $\mathrm{Li}$ et al., 2010). The water table fluctuation was a series of natural processes that are controlled by the water input (such as precipitation and surface inflow, etc.) and water output (such as evapotranspiration and runoff, etc.) (Zhang et al., 2002). A previous study employed daily standing water depth observation to drive $\mathrm{CH} 4 \mathrm{MOD}_{\text {wetland }}(\mathrm{Li}$ et al., 2010). When applying this model on a regional scale, empirical equations were used to estimate water table changes ( $\mathrm{Li}$ et al., 2004). Water table dynamics (WT, in $\mathrm{cm}$ ) are determined directly by the balance between the water input $\left(S_{\text {in }}, \mathrm{cm}\right)$, runoff $\left(F_{\text {out }}\right.$, $\mathrm{cm})$ and evapotranspiration $(\mathrm{ET}, \mathrm{cm})$. No runoff occurs during the period of freezing temperatures from November to March:

$\Delta \mathrm{WT}=\left\{\begin{array}{ll}S_{\text {in }}-F_{\text {out }}-\mathrm{ET} & (\text { Apr } \sim \text { Oct }) \\ \text { P-ET } & (\text { Nov } \sim \text { Mar })\end{array}\right.$,

$\mathrm{WT}_{i}=\mathrm{WT}_{i-1}+\Delta \mathrm{WT}$,

where $\mathrm{WT}_{i}$ represents the daily water table. Using WetlandDNDC, $S_{\text {in }}$ is a function of precipitation $(P)$, and $F_{\text {out }}$ includes surface outflow and ground outflow, both of which are determined by the water table (Zhang et al., 2002). The Priestley-Taylor model (Priestley and Taylor, 1972; Shuttleworth, 1992) was used to calculate ET (Sun and Song, 2008). 
The net radiation $\left(R_{\mathrm{n}}\right)$, which was used to calculate ET in the Priestley-Taylor model, was calculated using the equations of the modified Penmann-Monteith model (Allen et al., 1998). When the water table position value was less than zero, the standing water depth (WD) in CH4MOD wetland was considered to be zero.

The experimental constants $\left(\alpha_{0}, a_{1}, a_{2}, D_{1}, D_{2}\right)$ in the functions calculating $S_{\text {in }}$ and $F_{\text {out }}$ from Wetland-DNDC were calibrated by trial and error (Zhang et al., 2002). The values of the experimental constants for the main types of marshland on the Sanjiang Plain are shown in supplementary material B (Table B1).

\subsubsection{Sensitivity analysis}

A sensitivity analysis of $\mathrm{CH} 4 \mathrm{MOD}_{\text {wetland }}$ was performed to reveal the effects of the environmental drivers and model inputs on $\mathrm{CH}_{4}$ fluxes from the Deyeuxia angustifolia and Carex lasiocarpa sites from the year 2003 and 2004. The sensitivity

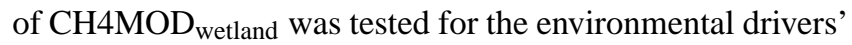
air temperature $\left(T_{\text {air }}\right.$ in $\left.{ }^{\circ}\right)$ and standing water depth (WD in $\mathrm{cm}$ ); the plant input parameter of the maximum aboveground biomass $\left(W_{\max }\right.$ in $\left.\mathrm{g} \mathrm{m}^{-2}\right)$, the vegetation index (VI), and the required growing degree days (GDD) for reaching maximum biomass $\left(\mathrm{GDD}_{\max }\right.$ in $\left.{ }^{\circ} \mathrm{d}\right)$; and the soil input parameters of the sand fraction (SAND), the soil bulk density ( $\rho$ in $\mathrm{g} \mathrm{cm}^{-3}$ ) and the concentration of soil organic matter (SOM in $\mathrm{g} \mathrm{kg}^{-1}$ ). The sensitivity of a given factor to the model's output was quantified as the ratio of the change in total seasonal $\mathrm{CH}_{4}$ flux $\left(\triangle \mathrm{CH}_{4}=\mathrm{CH}_{4}-\mathrm{CH}_{4}\right.$ _baseline $)$ to the $\mathrm{CH}_{4}$ flux at baseline $\left(\mathrm{CH}_{4}\right.$ baseline $)$.

\subsubsection{Uncertainty analysis}

In this study, we paid more attention on the uncertainties induced by the input of key parameters by using the extreme condition approach for uncertainty propagation (Du and Chen, 1999). The main input parameters for CH4MOD included soil sand percentage (SAND), organic matter amendment $\left(\mathrm{OM}\right.$ in $\left.\mathrm{g} \mathrm{m}^{-2}\right)$, rice grain yield $\left(\mathrm{GY}\right.$ in $\left.\mathrm{kg} \mathrm{h}^{-1}\right)$, water management pattern and rice cultivar index (RVI). Because of the limited data in water management pattern, the other four parameters (Table $\mathrm{C} 1$ in supplementary material $\mathrm{C}$ ) were chosen and 16 simulations were carried out for the rice paddy in each county or administrative farm. For $\mathrm{CH} 4 \mathrm{MOD}_{\text {wetland, }}$, totally six parameters (Table $\mathrm{C} 1$ ) were chosen and 64 simulations were carried out for the Carex lasiocarpa marshland and the Deyeuxia angustifolia marshland in each county or administrative farm, respectively. The parameters included VI, $W_{\max }, \mathrm{GDD}_{\max }$, SAND, $\rho$ and SOM. The maximum and minimum values of the input parameters represented the range of the corresponding parameters on the Sanjiang Plain.

\subsubsection{Simulating climatic factor impacts}

The climatic factors in $\mathrm{CH}_{4} \mathrm{MOD}_{\text {wetland }}$ and the empirical water table model include air temperature $\left(T_{\text {air }}\right)$, precipitation $(P)$ and net radiation $\left(R_{\mathrm{n}}\right)$. To quantify the impacts of climatic factors on the change in regional $\mathrm{CH}_{4}$ emissions and area-weighted $\mathrm{CH}_{4}$ fluxes from marshland on the Sanjiang Plain, simulations were conducted under both real climate conditions and different climate scenarios (Table 1) using $\mathrm{CH}_{4} \mathrm{MOD}_{\text {wetland }}$. Table 1 provides a description of the real climate condition and four climate scenarios. The real climate condition $\left(A_{T, P, R_{\mathrm{n}}}\right)$ means that observed data were used for all of the climatic factors (Table 1). $S_{T, P, R_{\mathrm{n}}}$ assumed that the annual mean $T_{\text {air }}, P$ and $R_{\mathrm{n}}$ of the last five decades were the same as in the 1950s, as if there was no climate change during the last six decades (Table 1). $S_{T, P}$ assumed that $T_{\text {air }}$ and $P$ from 1960 to 2009 were the same as in the $1950 \mathrm{~s}$, while observed data were used for $R_{\mathrm{n}}$ (Table 1). Similarly, $S_{T}$ and $S_{P}$ assumed that only $T_{\text {air }}$ or $P$ was the same as in the 1950s, respectively (Table 1).

$S_{T, P}$ (Table 1) is used as an example to explain how we simulated the annual $\mathrm{CH}_{4}$ flux for each county or administrative farm and annual regional $\mathrm{CH}_{4}$ emissions from the marshland of the Sanjiang Plain under the specified scenario. First, we randomly selected one year from 1950 to 1959 a total of 50 times and used the daily air temperature and the daily precipitation data series for the selected years to replace the corresponding climate data series of 1960-2009. The new $T_{\text {air }}$ and $P$ data series and the observed daily $R_{\mathrm{n}}$ data series for 1950-2009 were used to drive the model to simulate the annual $\mathrm{CH}_{4}$ flux for each county or administrative farm. Then, the above program was repeated 10 times to reduce the uncertainty caused by random selection. The average result of the 10 simulations is the annual $\mathrm{CH}_{4}$ flux under $S_{T, P}$ for the $k$-th county or administrative farm in the $i$-th year $F_{S_{T, P}}^{i, k}\left(\mathrm{~kg} \mathrm{ha}^{-1} \mathrm{yr}^{-1}\right)$. The area-weighted $\mathrm{CH}_{4}$ flux $\left(F^{i}\right.$ in $\left.\mathrm{kg} \mathrm{ha}^{-1} \mathrm{yr}^{-1}\right)$ is calculated by dividing the total emission of the entire region with the total marshland area in 1950. So the area-weighted $\mathrm{CH}_{4}$ flux is only the result of climate change, while the regional $\mathrm{CH}_{4}$ emission, including changes in methane flux and marshland area, is therefore driven by both climate change and the marshland conversion. $T_{S_{T, P}}^{i}\left(\mathrm{Tg} \mathrm{yr}^{-1}\right)$ represents the regional $\mathrm{CH}_{4}$ emissions in the $i$-th year under $S_{T, P}$, which is calculated using the following equation:

$$
T_{S_{T, P}}^{i}=\sum_{k=1}^{23} F_{S_{T, P}}^{i, k} \times\left(A^{i-1, k}-A C^{i-1, k}\right) / 10^{9},
$$

where $A^{i-1, k}$ (ha) represents the marshland area of the $k$ th county or administrative farm in the $(i-1)$-th year, and $A C^{i-1, k}$ (ha) represents the yearly area of marshland converted to cropland of the $k$-th county or administrative farm in the $i-1$-th year. 
Table 1. Description of the climate conditions for simulating $\mathrm{CH}_{4}$ emissions from 1950-2009.

\begin{tabular}{ccccccc}
\hline \multirow{2}{*}{ Climate } & Actual climate & & \multicolumn{5}{c}{ Scenario } \\
\cline { 2 - 4 } \cline { 5 - 7 } \cline { 5 - 7 } & $A_{T, P, R_{\mathrm{n}}}$ & & $S_{T, P, R_{\mathrm{n}}}$ & $S_{T, P}$ & $S_{T}$ & $S_{P}$ \\
\hline$T_{\text {air }}$ & $1950-2009$ & & $1950-1959$ & $1950-1959$ & $1950-1959$ & $1950-2009$ \\
$P$ & $1950-2009$ & & $1950-1959$ & $1950-1959$ & $1950-2009$ & $1950-1959$ \\
$R_{\mathrm{n}}$ & $1950-2009$ & & $1950-1959$ & $1950-2009$ & $1950-2009$ & $1950-2009$ \\
\hline
\end{tabular}

Similarly, the annual regional $\mathrm{CH}_{4}$ emissions under scenario $S_{T, P, R_{\mathrm{n}}}\left(T_{S_{T, P, R_{\mathrm{n}}}}^{i}\right.$ in $\left.\mathrm{Tg} \mathrm{yr}^{-1}\right), S_{T}\left(T_{S_{T}}^{i}\right.$ in $\left.\mathrm{Tg} \mathrm{yr}^{-1}\right)$ and $S_{P}\left(T_{S_{P}}^{i}\right.$ in $\mathrm{Tg} \mathrm{yr}^{-1}$ ) (Table 1$)$ can be calculated in the same way as scenario $S_{T, P}$.

The difference in simulated $\mathrm{CH}_{4}$ emissions (including the area-weighted $\mathrm{CH}_{4}$ flux and regional $\mathrm{CH}_{4}$ emissions) un$\operatorname{der} A_{T, P, R_{\mathrm{n}}}$ compared to the appointed climate scenario (Table 1 ) could represent the impact of the corresponding climatic factors on $\mathrm{CH}_{4}$ emissions (Eqs. 4 and 5). The difference in the simulated $\mathrm{CH}_{4}$ emissions under $A_{T, P, R_{\mathrm{n}}}$ compared to $S_{T, P, R_{\mathrm{n}}}$ is considered to be the impact of $T_{\text {air }}, P$ and $R_{n}$ on $\mathrm{CH}_{4}$ emissions. Similarly, the difference in simulated $\mathrm{CH}_{4}$ emissions under $A_{T, P, R_{\mathrm{n}}}$ compared to $S_{T, P}$ is considered to be the impact of $T_{\text {air }}$ and $P$ on $\mathrm{CH}_{4}$ emissions. The differences in simulated $\mathrm{CH}_{4}$ emissions under $A_{T, P, R_{\mathrm{n}}}$ compared to $S_{T}$ and $S_{P}$ are considered to be the impacts of $T_{\text {air }}$ and $P$ on $\mathrm{CH}_{4}$ emissions, respectively.

When analyzing the impact of climatic factors on regional $\mathrm{CH}_{4}$ emissions, the concomitant impact of marshland conversion could not be isolated. The impact of the specified climatic factors on the change of the regional $\mathrm{CH}_{4}$ emissions in the $j$-th decade $\left(I T_{\mathrm{CF}}^{j}\right.$ in $\mathrm{Tg}$ per decade) was calculated by:

$I T_{\mathrm{CF}}^{j}=\sum_{i}\left(T_{A_{T, P, R_{\mathrm{n}}}}^{i}-T_{S_{\mathrm{CF}}}^{i}\right)$,

where $T_{A_{T, P, R_{\mathrm{n}}}}^{i}\left(\mathrm{Tg} \mathrm{yr}^{-1}\right)$ and $T_{S_{C F}}^{i}\left(\mathrm{Tg} \mathrm{yr}^{-1}\right)$ represent the annual regional $\mathrm{CH}_{4}$ emissions under $A_{T, P, R_{\mathrm{n}}}$ and the appointed climate scenario (indicated by the subscript $S_{C F}$ ) in the $i$-th year, respectively. The subscript CF in $I T_{\mathrm{CF}}^{j}$ (Tg per decade) and $S_{\mathrm{CF}}$ represents the specified climatic factors. For example, when CF represents $T_{\text {air }}, P$ and $R_{\mathrm{n}}, I T_{T, P, R_{\mathrm{n}}}^{j}(\mathrm{Tg}$ per decade) represents the impact of $T_{\text {air }}, P$ and $R_{\mathrm{n}}$ on regional $\mathrm{CH}_{4}$ emissions, and $T_{S_{T, P, R_{\mathrm{n}}}^{i}}^{i}\left(\mathrm{Tg} \mathrm{yr}^{-1}\right)$ represents the annual regional $\mathrm{CH}_{4}$ emissions under scenario $S_{T, P, R_{\mathrm{n}}}$.

When analyzing the independent impacts of climatic factors on the area-weighted $\mathrm{CH}_{4}$ flux, we sought to isolate the impact of marshland conversion. The area-weighted $\mathrm{CH}_{4}$ flux $\left(F^{i}\right.$ in $\mathrm{kg} \mathrm{ha}^{-1} \mathrm{yr}^{-1}$ ) was used to calculate the independent impact of the climatic factors on the $\mathrm{CH}_{4}$ flux as follows:

$I F_{\mathrm{CF}}^{i}=F_{A_{T, P, R_{\mathrm{n}}}}^{i}-F_{S_{\mathrm{CF}}}^{i}$,
$P_{\mathrm{CF}}^{j}=\frac{\overline{I F_{\mathrm{CF}}^{j}}}{\overline{F_{A_{T, P, R \mathrm{n}}}^{1950 \mathrm{~s}}}}$,

where $I F_{\mathrm{CF}}^{i}\left(\mathrm{~kg} \mathrm{ha}^{-1} \mathrm{yr}^{-1}\right)$ represents the impact of the specified climatic factors (indicated by the subscript $\mathrm{CF}$ ) on the change in the area-weighted $\mathrm{CH}_{4}$ flux in the $i$-th year, and $F_{A_{T, P, R_{\mathrm{n}}}}^{i}\left(\mathrm{~kg} \mathrm{ha}^{-1} \mathrm{yr}^{-1}\right)$ and $F_{S_{\mathrm{CF}}}^{i}\left(\mathrm{~kg} \mathrm{ha}^{-1} \mathrm{yr}^{-1}\right)$ represent the area-weighted $\mathrm{CH}_{4}$ flux under $A_{T, P, R_{\mathrm{n}}}$ and the climate scenario (indicated by the subscript $S_{\mathrm{CF}}$ ) in the $i$-th year, respectively. $\overline{I F_{\mathrm{CF}}^{j}}\left(\mathrm{~kg} \mathrm{ha}^{-1} \mathrm{yr}^{-1}\right)$ represents the average impact of climatic factors on the area-weighted $\mathrm{CH}_{4}$ flux in the $j$-th decade. $\overline{F_{A_{T, P}, R_{\mathrm{n}}}^{1950 \mathrm{~s}}}\left(\mathrm{~kg} \mathrm{ha}^{-1} \mathrm{yr}^{-1}\right)$ represents the average area-weighted $\mathrm{CH}_{4}$ flux under $A_{T, P, R_{\mathrm{n}}}$ in the $1950 \mathrm{~s}$, assuming that no marshland conversion occurred. $P_{\mathrm{CF}}^{j}$ represents the proportion of $\overline{I F_{\mathrm{CF}}^{j}}$ to the average area-weighted $\mathrm{CH}_{4}$ flux under $A_{T, P, R_{\mathrm{n}}}$ in the 1950s in the $j$-th decade. The subscript $\mathrm{CF}$ in $I F_{\mathrm{CF}}^{i}, S_{\mathrm{CF}}, P_{\mathrm{CF}}^{j}$ and $\overline{I F_{\mathrm{CF}}^{j}}$ is the same as in Eq. (3).

\subsubsection{Predictions of the impact of climate change on $\mathrm{CH}_{4}$ flux}

In order to predict the independent impact of climate change on methane fluxes in the future, we assumed that other anthropogenic drivers that affect methane emissions remain as in the present. The climate change scenarios used in this study were RCP 2.6, RCP 4.5, RCP 6.0 and RCP 8.5, which were projected by the Flexible Global Ocean-AtmosphereLand System climate model (FGOALS, Yu et al., 2002, 2004). More information about the RCP scenarios is given in supplementary material D.

FGOALS is a GCM (General Circulation Model) that contributed to the 5th assessment report (AR5) of the IPCC. It has a spatial resolution of $1.65^{\circ}$ latitude by $2.8^{\circ}$ longitude. The outputs of FGOALS were spatially downscaled to the 7 meteorological stations across the Sanjiang Plain using the delta change method (Hay et al., 2000; Beldring et al., 2008; Prudhomme et al., 2002). The delta change method is used to compute differences between current and future GCM simulations and to add these changes to observed time series (Hay et al., 2000). In this study, we chose the representative longterm average of 1961-1990 as the current or baseline period 
(Prudhomme et al., 2002; Wilby et al., 2004), as this is the standard World Meteorological Organization period (Hulme et al., 1995). The simulated average area-weighted $\mathrm{CH}_{4}$ flux for 1961-1990 represents the baseline $\mathrm{CH}_{4}$ flux from the marshland of the Sanjiang Plain. We focused on the future time horizons of the 2030s (2011-2040), 2050s (2041-2070) and 2080s (2071-2100). $\mathrm{CH}_{4}$ fluxes were simulated for each county or administrative farm using $\mathrm{CH} 4 \mathrm{MOD}_{\text {wetland, which }}$ was driven by the downscaled output data from FGOALS. The area-weighted $\mathrm{CH}_{4}$ flux for 2010-2100 is derived from the proportion of the marshland area in each county or administrative farm within the whole area of the Sanjiang Plain in 2009. The changes in the average area-weighted $\mathrm{CH}_{4}$ fluxes for the 2030s, 2050s and 2080s relative to the baseline $\mathrm{CH}_{4}$ flux represent the predicted impact of climate change on $\mathrm{CH}_{4}$ fluxes from the marshland of the Sanjiang Plain.

\subsection{Data sources}

\subsubsection{Changes in marshland and rice paddy areas}

It is reported that wetland loss in northeast China is mainly caused by reclamation (Liu and Ma, 2000; Gong et al., 2010; An et al., 2007). According to Wang et al. (2009), an estimated $2.58 \mathrm{M}$ ha of marshland was converted to cropland on the Sanjiang Plain over the period from 1954-2005, which is compared to an increase of the cropland area from the official statistical reports (Su and Zhang, 2008) from the 1950 s to the 2000s. Therefore, we used the yearly increase in cropland area taken from the annual statistical reports for a county or at the scale of an administrative farm ( $\mathrm{Su}$ and Zhang, 2008) to calculate the yearly area of marshland converted to cropland from 1950 to 2009 . The marshland area in each county in 1950 was calculated by totaling the cropland area (Su and Zhang, 2008) and marshland area (Wang et al., 2002) in 1980 and then subtracting the cropland area from 1950 (Su and Zhang, 2008). The marshland area on administrative farms in 1950 was obtained from the local chronicles of the reclamation system of Heilongjiang province (http://www.zglz.gov.cn/nongken/index.html). According to Cui (1997), the marshland area is mainly vegetated with Deyeuxia angustifolia and Carex plants, which account for approximately $20 \%$ and $80 \%$ of the vegetation on the Sanjiang Plain, respectively.

The yearly acreage and yields of irrigated rice from 1950 to 2009 were obtained from the statistical yearbook of Heilongjiang province at the scale of a county or an administrative farm.

\subsubsection{Model input data}

The environmental drivers of $\mathrm{CH}_{4} \mathrm{MOD}_{\text {wetland }}$ include the daily air temperature and standing water depth ( $\mathrm{Li}$ et al., 2010). Meteorological datasets from 7 meteorological stations across the Sanjiang Plain from 1950-2009 were acquired from the China Meteorological Administration (CMA) (http://cdc.cma.gov.cn/). Daily standing water depth data were calculated using the empirical water table model. We used the water table states to be the initial water table value of 1950 . The water table states were obtained by a $1-$ year spin-up simulation by the water table empirical model, the forcing for which were the average climate data of 19501959. Inputs for the empirical water table model, such as daily precipitation, hours of sunshine, maximum/minimum temperatures, and relative humidity, were also obtained from the CMA. The projected meteorological datasets were outputs of FGOALS, which were provided by the State Key Laboratory of Numerical Modeling for Atmospheric Sciences and Geophysical Fluid Dynamics (LASG), the Institute of Atmospheric Physics (IAP), the Chinese Academy of Sciences (CAS). For counties or administrative farms for which meteorological data were not available, we used the data from the neighboring site. The key parameters of plant and

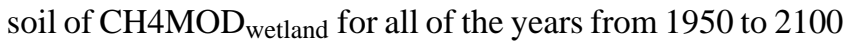
were described as the baseline value in Table $\mathrm{C} 1$ in supplementary material C. More details about input parameters of CH4MOD $_{\text {wetland }}$ were described in $\mathrm{Li}$ et al. (2010).

For the uncertainty analysis on the key parameters of $\mathrm{CH}_{4} \mathrm{MOD}_{\text {wetland, }}$, the maximum and minimum values of VI were supposed to be $\pm 10 \%$ of the baseline value (Table $\mathrm{C} 1$ ). The maximum and minimum values of the maximum above ground biomass of Carex lasiocarpa and Deyeuxia angustifolia marshland were from the published observed data (Table C1). According to Ma et al. (1996) and Yang et al. (2002), the maximum value of aboveground biomass appears from July to August. Correspondingly, the range of average $\mathrm{GDD}_{\max }$ was around $1200-2500^{\circ} \mathrm{d}$. The maximum and minimum values of SAND and SOM were referred to the soil database developed by the Institute of Soil Sciences, Chinese Academy of Sciences when it was not reported. The bulk density $\rho$ was related to the SOM value.

Field measurements of the water table and the annual $\mathrm{CH}_{4}$ flux in marshlands of Deyeuxia angustifolia from 2003 to 2004 and Carex lasiocarpa from 2003 to 2005 (Hao et al., 2006; Song et al., 2007) were used to calibrate and validate the empirical water table model. However, the above papers (Hao et al., 2006; Song et al., 2007) only reported the $\mathrm{CH}_{4}$ flux in the growing season (April to October). According to Yang et al. (2006b), the $\mathrm{CH}_{4}$ flux in the non-growing season (November to March) represents $\sim 4 \%$ of the total yearly flux on the Sanjiang Plain. This relationship was used to calculate the annual $\mathrm{CH}_{4}$ flux in this study. More details about these measurements were described by Li et al. (2010). Measurements of the daily evapotranspiration and net radiation on the Sanjiang Plain during the period from 2005 to 2007 (Zhao et al., 2008; Jia et al., 2010) were used to validate the intermediate results of the empirical water table model. The observed $\mathrm{CH}_{4}$ fluxes (Huang et al., 2010; Ding et al., 2004; Song et al., 2007; Hao et al., 2004; Cui, 1997; Cui et al., 1998; Zhou et al., 2006; Wang et al., 2003b) were used 
to make a comparison to the simulated range of the annual area-weighted $\mathrm{CH}_{4}$ fluxes from the marshland of the Sanjiang Plain by the uncertainty analysis. The literature (Ding et al., 2004; Hao et al., 2004; Zhou et al., 2006; Wang et al., 2003b) reported $\mathrm{CH}_{4}$ fluxes during May to October. To obtain annual fluxes, these datasets were corrected using the method of Huang et al. (2010).

For CH4MOD, the environmental driver is the daily air temperature. The database of input parameters was described by Huang et al. (2006). For the uncertainty analysis, the maximum and minimum values of RVI, GY and OM were supposed to be $\pm 10 \%$ of the baseline value. The range of the soil sand fraction was the same as in the $\mathrm{CH} 4 \mathrm{MOD}_{\text {wetland }}$. The GY, OM and SAND were at the scale of a county or an administrative farm. More details about the range of parameter values for uncertainty analysis are described in Table $\mathrm{C} 1$.

\section{Results and discussion}

\subsection{Model validation and sensitivity analysis}

$\mathrm{CH}_{4} \mathrm{MOD}_{\text {wetland }}$ coupled with the empirical water table model can basically simulate the seasonal variations in standing water depth (Fig. E1a and b) and $\mathrm{CH}_{4}$ fluxes (Fig. E1c and d). The performance of $\mathrm{CH}_{4} \mathrm{MOD}_{\text {wetland }}$ was also good for the total annual/seasonal $\mathrm{CH}_{4}$ fluxes (Fig. E2b). Details of model validation and sensitivity analysis of $\mathrm{CH} 4 \mathrm{MOD}_{\text {wetland }}$ are described in supplementary material E.

\subsection{Temporal and spatial $\mathrm{CH}_{4}$ variation from 1950- 2009}

\subsubsection{Changes in marshland area due to the conversion of marshland to cropland}

The marshland area on the Sanjiang Plain decreased by $3.2 \mathrm{M}$ ha due to intensive cultivation over the period from 19502009 (Fig. 2). Extensive conversion of marshland to cropland occurred in the 1950s and 1970s when cropland increased at a rate of $0.05-0.06 \mathrm{M} \mathrm{ha} \mathrm{yr}^{-1}$, and marshland loss occurred at a rate of $\sim 0.06 \mathrm{M} \mathrm{ha} \mathrm{yr}^{-1}$. From 1960 to 1966, cropland increased by $0.54 \mathrm{Mha}$, and the loss of marshland was serious. However, from 1966 to 1970, grievous natural disasters (Group of Chinese Wetland Resources Development and Environmental Protection, 1998) caused farmers to lose their enthusiasm of cultivation and to abandon large areas of cropland (Ma, 1999). We assumed that the abandoned cropland was reverted to marshland; thus, the marshland area increased during the period from 1966-1970. From 1980 to 1999 , marshland decreased at a rate of $0.03 \mathrm{M} \mathrm{ha} \mathrm{yr}^{-1}$. During the 2000s, cropland increased extensively (Fig. 2), and marshland decreased by $\sim 1.1 \mathrm{M}$ ha (Fig. 2 ).

The proportion of the area of irrigated rice was relatively low when marshland was converted to cropland before the mid-1990s, though it increased substantially thereafter

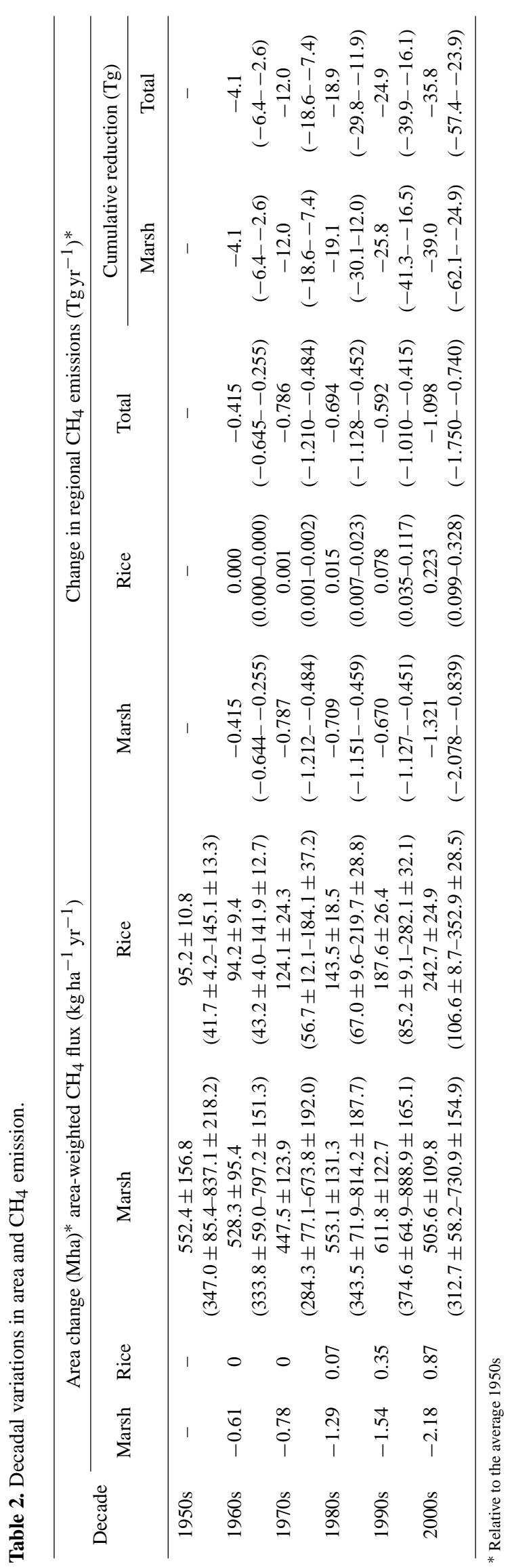

Biogeosciences, 9, 5199-5215, 2012 


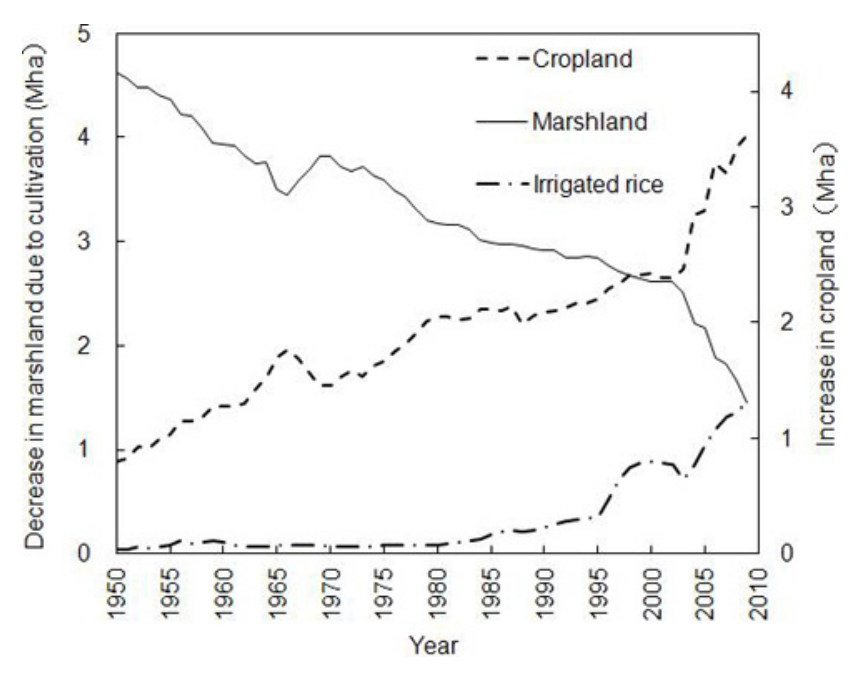

Fig. 2. Conversion of marshland to cropland on the Sanjiang Plain.

(Fig. 2). In the 2000s, the irrigated rice area accounted for $33 \%$ of the total cultivated area (Heilongjiang Provencal Bureau of Statistics, 2010). Table F1 (supplementary material F) shows the spatiotemporal changes in the marshland and irrigated rice areas on the Sanjiang Plain.

Marshland on the Sanjiang Plain was converted for different land uses over the period 1949-2000, including for cropland, grassland, woodland and urbanization (Wang et al., 2003a; Zhang et al., 2010), which were unavailable for quantification not only in the yearly sequence from 1950 to 2009 but also at the county scale (Fig. 1). This study only focuses on the conversion of marshland to cropland (Fig. 2). Based on data retrieved from remote sensing images from 1976, 1986, 1995, 2000 and 2005, an estimated 2.58 M ha of marshland was converted to cropland on the Sanjiang Plain over the period of 1954-2005 (Wang et al., 2009), which agrees with our estimate of 2.45 M ha (from 1950-2005).

\subsubsection{Temporal variation of $\mathrm{CH}_{4}$ emissions}

Based on the models and the statistical area datasets, the mean annual area-weighted $\mathrm{CH}_{4}$ fluxes and the variation in regional $\mathrm{CH}_{4}$ emissions in the marshland and rice paddies of the Sanjiang Plain were estimated for the past 6 decades (Table 2). The variation in the mean annual area-weighted $\mathrm{CH}_{4}$ flux from the marshland was mainly influenced by the climate. The minimum area-weighted $\mathrm{CH}_{4}$ flux from the marshland occurred in the 1970s (Table 2), together with the lowest precipitation (Fig. 4b). After the 1970s, due to the higher air temperatures and precipitation in the 1980s and 1990s (Fig. 4a and b), the area-weighted $\mathrm{CH}_{4}$ flux reached its maximum value of $611.8 \pm 122.7 \mathrm{~kg} \mathrm{ha}^{-1} \mathrm{yr}^{-1}$ (374.6 \pm $64.9-888.9 \pm 165.1 \mathrm{~kg} \mathrm{ha}^{-1} \mathrm{yr}^{-1}$ ) in the 1990s (Table 2). Although the mean annual temperature was still high $\left(3.93^{\circ}\right)$ (Fig. 4a), the mean annual area-weighted $\mathrm{CH}_{4}$ flux was reduced to $505.6 \pm 109.8 \mathrm{~kg} \mathrm{ha}^{-1} \mathrm{yr}^{-1}(312.7 \pm 58.2-730.9 \pm$
$154.9 \mathrm{~kg} \mathrm{ha}^{-1} \mathrm{yr}^{-1}$ ) (Table 2) due to the lower precipitation in the 2000s (Fig. 4b). Under the conditions of marshland being converted to cropland and climate change, the mean annual regional $\mathrm{CH}_{4}$ emissions decreased by $1.3 \mathrm{Tg} \mathrm{yr}^{-1}(0.8-$ $2.1 \mathrm{Tg} \mathrm{yr}^{-1}$ ) in the 2000 s compared with the average in the 1950 s, with a $\sim 55 \%$ reduction of the simulated average regional $\mathrm{CH}_{4}$ emissions in the 1950s from the marshland (Table 2$)$. The average reduction rate was $\sim 0.26 \mathrm{Tg}(0.17-$ $0.42 \mathrm{Tg}$ ) per decade over the past 6 decades.

After marshland was converted to rice paddies, the $\mathrm{CH}_{4}$ fluxes reduced remarkably (Table 2). This corresponds to the measurements which indicated that marshland conversion to rice fields decreased $\mathrm{CH}_{4}$ fluxes significantly, with a reduction of $28-73 \%$ on the Sanjiang Plain (Huang et al., 2010). In rice fields, the mean annual area-weighted $\mathrm{CH}_{4}$ flux has increased by $\sim 150 \%$ over the past 6 decades (Table 2 ). The two most important reasons for this increase were that the grain yield in the 2000s was approximately 2 times higher than that in the 1950s, and the observed air temperature has increased significantly over the last 50 years (Editorial Committee of China's National Assessment Report on Climate Change, 2007). A significant increase in the mean annual regional $\mathrm{CH}_{4}$ emissions from rice fields has been observed since the 1980s (Table 2), which corresponds to the increase in the area of rice fields (Table 2).

As a result, the mean annual regional $\mathrm{CH}_{4}$ emissions from the Sanjiang Plain decreased by $1.1 \mathrm{Tg} \mathrm{yr}^{-1}(0.7-$ $1.8 \mathrm{Tg} \mathrm{yr}^{-1}$ ) during the past 6 decades, about half of the levels in the 1950s (Table 2). The cumulative reduction in regional $\mathrm{CH}_{4}$ emissions totaled $36 \mathrm{Tg}(24-57 \mathrm{Tg}$ ) over the past 5 decades relative to the average emissions in the 1950s (Table 2). The cumulative reduction of $\mathrm{CH}_{4}$ by $\sim 25 \mathrm{Tg}$ (16$40 \mathrm{Tg}$ ), resulting from the conversion of marshland to cropland and climate change over the 1960s-1990s (Table 2), is comparable with the previous estimate of $27 \mathrm{Tg}$ (Huang et al., 2010).

\subsubsection{Spatial variation of regional $\mathrm{CH}_{4}$ emissions}

Using $\mathrm{CH} 4 \mathrm{MOD}_{\text {wetland }}$ and $\mathrm{CH} 4 \mathrm{MOD}$, the variations in the mean annual regional $\mathrm{CH}_{4}$ emissions by county and administrative farm from marshland and rice paddies over the past 6 decades were simulated (Table G1 in supplementary material G). Variations in the total amount of $\mathrm{CH}_{4}$ emissions mainly occurred on the administrative farms (Table G1), where extensive marshland conversion took place (Table F1). For marshland, the decrease of mean annual regional $\mathrm{CH}_{4}$ emissions accounted for $54 \%$ and $46 \%$ of the total reduction on the 3 administrative farms and the 23 counties during the past 6 decades, respectively (Table G1). For the rice paddies, the increase of the mean annual regional $\mathrm{CH}_{4}$ emissions accounted for $58 \%$ and $42 \%$ of the total increase on the 3 administrative farms and the 23 counties from the 1950s to the 2000s, respectively (Table G1). More specific details about 

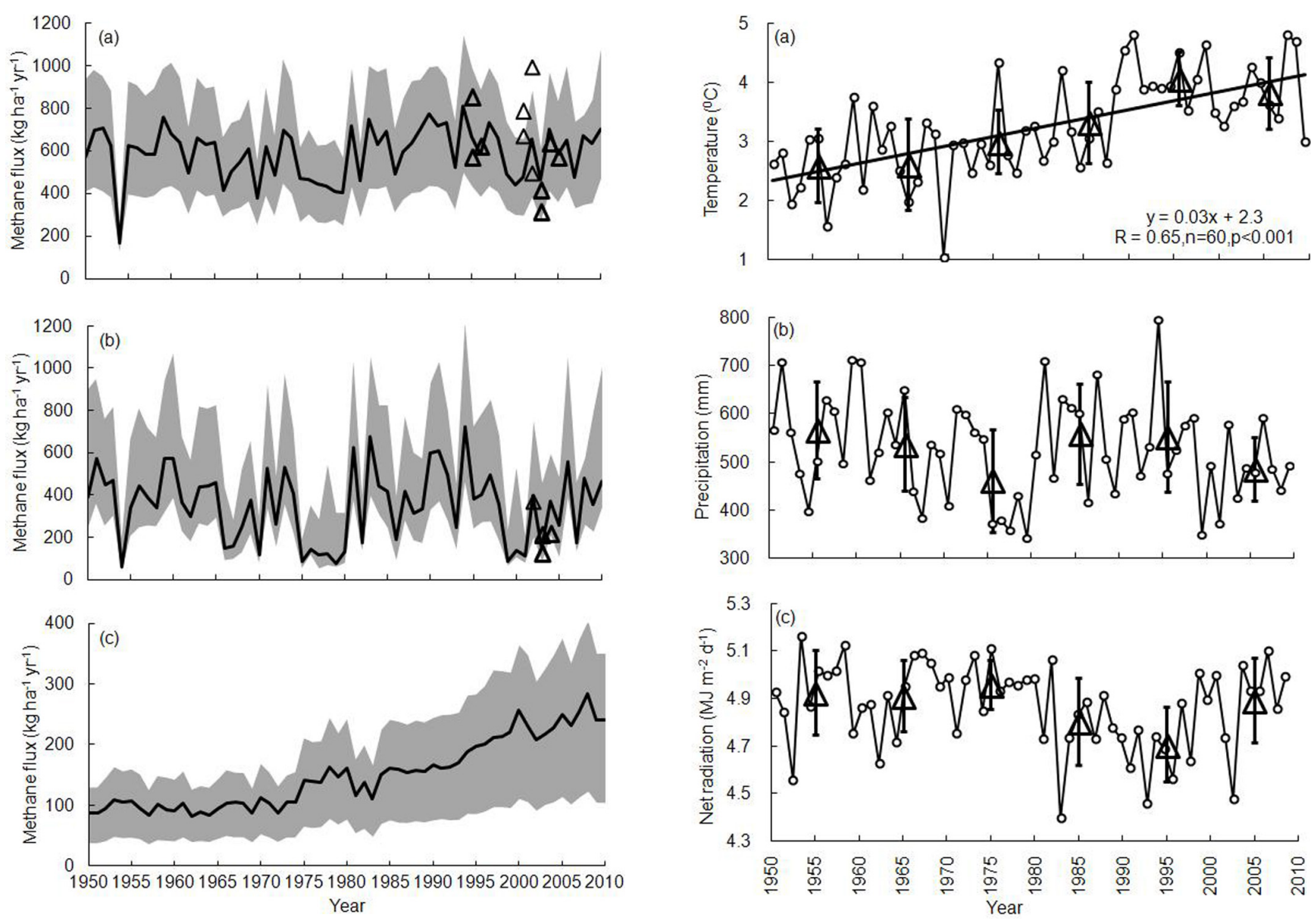

Fig. 3. Uncertainty analysis of $\mathrm{CH}_{4}$ fluxes from marshland and rice paddies on the Sanjiang Plain.

the spatial variation of $\mathrm{CH}_{4}$ emissions are given in supplementary material G.

\subsubsection{Uncertainty analysis of $\mathrm{CH}_{4}$ fluxes}

Figure 3 shows the uncertainty of the area-weighted $\mathrm{CH}_{4}$ fluxes over the marshland (Fig. 3a and b) and the rice paddy (Fig. 3c). The shaded area represents the simulated range of $\mathrm{CH}_{4}$ fluxes over the marshland (Fig. 3a and b) by 64 simulations and over the rice paddy (Fig. 3c) by 16 simulations, respectively. The maximum annual area-weighted $\mathrm{CH}_{4}$ fluxes were 807.3 (496.1-1139.4) $\mathrm{kg} \mathrm{ha}^{-1} \mathrm{yr}^{-1}$ for Carex lasiocarpa marshland (Fig. 3a) and 720.5 (459.11214.6) $\mathrm{kg} \mathrm{ha}^{-1} \mathrm{yr}^{-1}$ for Deyeuxia angustifolia marshland (Fig. 3b) in 1994. The maximum $\mathrm{CH}_{4}$ fluxes were mainly due to the higher temperature $\left(4.0^{\circ}\right.$ in Fig. $\left.4 \mathrm{a}\right)$ and the highest precipitation $(797 \mathrm{~mm}$ in Fig. $4 \mathrm{~b})$. The minimum areaweighted $\mathrm{CH}_{4}$ fluxes were 167.7 (129.0-265.4) $\mathrm{kg} \mathrm{ha}^{-1} \mathrm{yr}^{-1}$ for Carex lasiocarpa marshland (Fig. 3a) and 62.1 (39.4191.2) $\mathrm{kg} \mathrm{ha}^{-1} \mathrm{yr}^{-1}$ for Deyeuxia angustifolia marshland (Fig. 3b) in 1954. The minimum values were attributed to the

lower temperature ( $3^{\circ}$ in Fig. $\left.4 \mathrm{a}\right)$ and precipitation $(399 \mathrm{~mm}$ in Fig. 4b).

We also conducted a comparison of the simulated areaweighted $\mathrm{CH}_{4}$ fluxes with the observed $\mathrm{CH}_{4}$ fluxes from previous studies. The triangles represent the observed $\mathrm{CH}_{4}$ fluxes in the Carex lasiocarpa marshland (Fig. 3a) (Ding et al., 2004; Song et al., 2007; Hao et al., 2004; Cui, 1997; Cui et al., 1998; Zhou et al., 2006; Wang et al., 2003b) and in the Deyeuxia angustifolia marshland (Fig. 3b) (Huang et al., 2010; Song et al., 2007; Zhou et al., 2006). The results showed that most of the observed $\mathrm{CH}_{4}$ fluxes were in the range of the simulated $\mathrm{CH}_{4}$ fluxes (Fig. $3 \mathrm{a}$ and b). The simulated annual variations of the $\mathrm{CH}_{4}$ fluxes were also consistent with the observed values (Fig. 3a and b). For example, in 2002, the precipitation was $580 \mathrm{~mm} \mathrm{yr}^{-1}$ (Fig. 4a), and the simulated annual area-weighted $\mathrm{CH}_{4}$ fluxes were $381.6-882.3 \mathrm{~kg} \mathrm{ha}^{-1} \mathrm{yr}^{-1}$ in the Carex lasiocarpa marshland (Fig. 3a) and $169.4-745.9 \mathrm{~kg} \mathrm{ha}^{-1} \mathrm{yr}^{-1}$ in the Deyeuxia 
angustifolia marshland (Fig. 3b). Correspondingly, the observed $\mathrm{CH}_{4}$ fluxes were $493.7-991.8 \mathrm{~kg} \mathrm{ha}^{-1} \mathrm{yr}^{-1}$ in the Carex lasiocarpa marshland (Fig. 3a) (Ding et al., 2004; Hao et al., 2004) and 368.9 in the Deyeuxia angustifolia marshland (Fig. 3b) (Huang et al., 2010). During a dryer year in 2003, with an annual precipitation of $427 \mathrm{~mm}$ (Fig. 4a), the simulated annual area-weighted $\mathrm{CH}_{4}$ flux was lower than in 2002. The annual area-weighted $\mathrm{CH}_{4}$ fluxes were $269.1-611.3 \mathrm{~kg} \mathrm{ha}^{-1} \mathrm{yr}^{-1}$ in the Carex lasiocarpa marshland (Fig. 3a) and 83.6-454.4 $\mathrm{kg} \mathrm{ha}^{-1} \mathrm{yr}^{-1}$ in the Deyeuxia angustifolia marshland (Fig. $3 \mathrm{~b}$ ). The observed $\mathrm{CH}_{4}$ fluxes were also lower in 2003 than in 2002, with the values of $313.5-416.6 \mathrm{~kg} \mathrm{ha}^{-1} \mathrm{yr}^{-1}$ in the Carex lasiocarpa marshland (Fig. 3a) (Song et al., 2007; Zhou et al., 2006) and 122.9$209.3 \mathrm{~kg} \mathrm{ha}^{-1} \mathrm{yr}^{-1}$ in the Deyeuxia angustifolia marshland (Fig. 3b) (Song et al., 2007; Zhou et al., 2006; Huang et al., 2010).

There was no significant trend of $\mathrm{CH}_{4}$ flux from marshland from 1950 to 2009, although a strong interannual variation was shown (Fig. 3a and b). However, a significant increasing trend of $\mathrm{CH}_{4}$ fluxes from rice paddies from 1950 to 2009 was observed (Fig. 3c). During the past 60 years, the significant increasing rate of annual area-weighted $\mathrm{CH}_{4}$ flux was 2.95 $(1.3-4.3) \mathrm{kg} \mathrm{ha} \mathrm{yr}^{-1}(P<0.001)$ from rice paddies.

Uncertainties may come from a lot of imperfections, such as the assumptions in model structure and key parameters, limited abundance of the model input data and spatial resolution etc. (King et al., 1991; van Bodegom et al., 2000). Comprehensive uncertainty analysis is the major concern in modeling studies (Ogle et al., 2003, 2010). In this study, we induced the uncertainty of $\mathrm{CH}_{4}$ flux via the input of key parameters. However, when simulating regional $\mathrm{CH}_{4}$ emissions associated with marshland conversion to cropland on the Sanjiang Plain from 1950 to 2009, there are several other limitations in the models and data that need further improvement in future. First, we used the available meteorological data from seven counties. For other counties or administrative farms, we used data from a neighboring site. This coarse spatial replacement may conceal the detailed spatial variation of climatic parameters to some extent. However, the differences in climate between the sites that cover the Sanjiang Plain were not significant. The standard deviations for precipitation and the air temperature were $33 \mathrm{~mm}(\sim 6 \%$ of the average annual mean precipitation from 1950-2009 at the 7 sites $)$ and $0.35^{\circ}(\sim 10 \%$ of the average annual mean air temperature from 1950-2009 at the 7 sites), respectively. Therefore, there may be some slight uncertainty caused by this coarse spatial replacement and a finer resolution of meteorological data might be needed when using the model at a larger scale in the future. Second, there may be uncertainty in estimating the conversion area from marshland to cropland. And it might induce uncertainties in the estimated regional $\mathrm{CH}_{4}$ emissions. However, it is difficult to carry out comprehensive uncertainty analysis of $\mathrm{CH}_{4}$ emissions associated with marshland conversion, because the sufficient data of marsh- land conversion is unavailable in annual sequence from 1950 to 2009 at a higher spatial resolution. At present, the obtained data of marshland conversion can only support a baseline simulation of the annual methane emission changes at a lower spatial resolution. We will pay more attention on the uncertainty induced by the marshland conversion area when more data are available in future. Last but not least, the limitation of model structure and coefficients might cause uncertainty. For example, during the conversion of marshland to rice paddy, either biological substrate or physiochemical processes might change (Xu and Tian, 2012). The model approach could simulate $\mathrm{CH}_{4}$ flux before marshland conversion by $\mathrm{CH} 4 \mathrm{MOD}_{\text {wetland, }}$, and after the marshland conversion to rice paddies by $\mathrm{CH} 4 \mathrm{MOD}$. However, neither model could simulate the process of marshland converted to rice paddy. Moreover, the $\mathrm{CH} 4 \mathrm{MOD}$ wetland could not simulate the $\mathrm{CH}_{4}$ flux in response to the elevated $\mathrm{CO}_{2}$, nor could it simulate the impact of climate change on marshland loss. All of the limitations about model approach might induce uncertainties in simulating $\mathrm{CH}_{4}$ emissions. Improvements on the model structure will be needed in the future.

\subsection{Impact of marshland conversion and climate change on $\mathrm{CH}_{4}$ emissions from marshland from 1950-2009}

\subsubsection{Changes in climatic factors from 1950-2009}

Figure 4 shows the interannual and interdecadal variations in the area-weighted air temperature (Fig. 4a), precipitation (Fig. 4b) and net radiation (Fig. 4c) on the Sanjiang Plain from 1950 to 2009. There was a significant increasing trend in the mean annual air temperature (linear trend with $P<0.001$ ), with an increase rate of $0.3^{\circ}$ per decade. An obvious increase in the air temperature has occurred since the 1980s, and the maximum mean annual temperature occurred in the 1990s (Fig. 4a). The mean annual precipitation and net radiation showed great interannual variation, but without an obvious trend (linear trend with $P>0.05$ ) (Fig. $4 \mathrm{~b}$ and c). The minimum mean annual precipitation was observed in the 1970s, followed by the 2000s (Fig. 4b). The net radiation was low in the 1980s and 1990s (Fig. 4c).

These climatic factors can influence $\mathrm{CH}_{4}$ emissions in three ways. First, a higher temperature will enhance the rate of microbial $\mathrm{CH}_{4}$ production, and it will affect the length of the growing season by influencing the growing degree days (GDD). Second, increase of precipitation may result in a higher water table position and subsequently accelerate $\mathrm{CH}_{4}$ flux. Third, higher net radiation could increase evapotranspiration and thereby lower the water table, which would decrease $\mathrm{CH}_{4}$ flux. 
Table 3. Impact of climatic factors on $\mathrm{CH}_{4}$ variation.

\begin{tabular}{|c|c|c|c|c|c|c|c|c|}
\hline \multirow{2}{*}{ Decade } & \multicolumn{4}{|c|}{ Impact on regional $\mathrm{CH}_{4}$ emissions $(\mathrm{Tg})^{\mathrm{a}}$} & \multicolumn{4}{|c|}{ Impact on area-weighted $\mathrm{CH}_{4}$ flux ${ }^{\mathrm{b}}$} \\
\hline & $I T_{T}$ & $I T_{P}$ & $I T_{T, P}$ & $I T_{T, P, R_{\mathrm{n}}}$ & $P_{T}$ & $P_{P}$ & $P_{T, P}$ & $P_{T, P, R_{\mathrm{n}}}$ \\
\hline $1960 \mathrm{~s}$ & -1.10 & 0.16 & -0.56 & -0.24 & $-5.7 \%$ & $1.7 \%$ & $-2.6 \%$ & $-1.0 \%$ \\
\hline $1970 \mathrm{~s}$ & -1.08 & -4.09 & -4.32 & -4.10 & $-5.6 \%$ & $-21.1 \%$ & $-22.7 \%$ & $-21.6 \%$ \\
\hline $1980 \mathrm{~s}$ & -0.01 & -1.78 & -1.24 & -0.75 & $-0.2 \%$ & $-9.4 \%$ & $-6.5 \%$ & $-3.9 \%$ \\
\hline 1990s & 0.82 & 0.11 & 0.96 & 1.57 & $5.1 \%$ & $0.4 \%$ & $7.2 \%$ & $10.8 \%$ \\
\hline $2000 \mathrm{~s}$ & 0.13 & -2.80 & -2.15 & -1.86 & $1.7 \%$ & $-21.1 \%$ & $-14.9 \%$ & $-12.2 \%$ \\
\hline
\end{tabular}

${ }^{a}$ Used Eq. (4), positive/negative values represent increase/decrease regional $\mathrm{CH}_{4}$ emissions.

${ }^{b}$ Used Eq. (5), positive/negative values represent increase/decrease area-weighted $\mathrm{CH}_{4}$ flux.

$I T_{T}$ : Impact of air temperature on regional $\mathrm{CH}_{4}$ emissions.

$I T_{P}$ : Impact of precipitation on regional $\mathrm{CH}_{4}$ emissions.

$I T_{T, P}$ : Impact of air temperature and precipitation on regional $\mathrm{CH}_{4}$ emissions.

$I T_{T, P, R_{\mathrm{n}}}$ : Impact of air temperature, precipitation and net radiation on regional $\mathrm{CH}_{4}$ emissions.

$P_{T}$ : Impact of air temperature on area-weighted $\mathrm{CH}_{4}$ flux.

$P_{P}$ : Impact of precipitation on area-weighted $\mathrm{CH}_{4}$ flux

$P_{T, P}$ : Impact of air temperature and precipitation on area-weighted $\mathrm{CH}_{4}$ flux.

$P_{T, P, R_{\mathrm{n}}}$ : Impact of air temperature, precipitation and net radiation on area-weighted $\mathrm{CH}_{4}$ flux.

\subsubsection{Impact of marshland conversion and climate change on regional $\mathrm{CH}_{4}$ emissions}

Both marshland conversion and climate change have contributed to regional $\mathrm{CH}_{4}$ decreases over the past 6 decades in the marshland of the Sanjiang Plain. If no climate change had taken place, marshland conversion alone could account for a cumulative $\mathrm{CH}_{4}$ reduction of $33.6 \mathrm{Tg}$ from 1960 to 2009 relative to the 1950s (calculated based on the simulated annual regional $\mathrm{CH}_{4}$ emissions under scenario $\left.S_{T, P, R_{\mathrm{n}}}\right)$. Climate change alone could account for a cumulative $\mathrm{CH}_{4}$ reduction of 5.4 Tg from 1960 to 2009 relative to the 1950 s (calculated based on the difference between the simulated annual regional $\mathrm{CH}_{4}$ emissions under $A_{T, P, R_{\mathrm{n}}}$ and scenario $S_{T, P, R_{\mathrm{n}}}$ ). Table 2 shows that the simulated cumulative $\mathrm{CH}_{4}$ reduction under the conditions of climate change and marshland conversion was $39.0 \mathrm{Tg}$ in the marshland (Table 2). Thus, marshland conversion contributed $86 \%$ of the regional reduction in $\mathrm{CH}_{4}$ emissions, and climate change contributed $14 \%$ from the marshland.

\subsubsection{Impact of climatic factors on regional $\mathrm{CH}_{4}$ emissions}

The impact of climatic factors on the variation in regional $\mathrm{CH}_{4}$ emissions is shown in Table 3. As the air temperature increased (Fig. 4a), the impact of the air temperature on regional $\mathrm{CH}_{4}$ emissions showed a linear increase of $0.44 \mathrm{Tg}$ per decade ( $R=0.83, P=0.08)$. The increasing air temperature enhanced regional $\mathrm{CH}_{4}$ emissions significantly in the $1990 \mathrm{~s}$ and 2000s (Table 3), corresponding to the obvious increase in air temperature in the 1990s and 2000s (Fig. 4a). The impact of precipitation and net radiation on regional $\mathrm{CH}_{4}$ emissions showed obvious interdecadal variation. Precipitation was the main contributor to regional $\mathrm{CH}_{4}$ variation because it controlled the water table position, which can markedly affect
$\mathrm{CH}_{4}$ flux (Fig. E1) (Boon et al., 1997; Ding et al., 2002). The maximum reduction in regional $\mathrm{CH}_{4}$ emissions amounted to $4.09 \mathrm{Tg}$ in the $1970 \mathrm{~s}$, followed by $2.80 \mathrm{Tg}$ in the $2000 \mathrm{~s}$ (Table 3), due to the lower precipitation in 1970s and 2000s (Fig. 4b). The influence of the interannual/interdecadal variation in precipitation on regional $\mathrm{CH}_{4}$ emissions may obscure the acceleration of $\mathrm{CH}_{4}$ emissions caused by the increasing air temperature. Therefore, the concurrent influence of air temperature and precipitation $\left(\mathrm{IT}_{T, P}\right)$ showed a similar trend to the influence of precipitation alone $\left(\mathrm{IT}_{P}\right)$ on regional $\mathrm{CH}_{4}$ emissions (Table 3).

\subsubsection{Impact of climatic factors on area-weighted $\mathrm{CH}_{4}$ flux}

The decadal and annual impacts of climatic factors on the area-weighted $\mathrm{CH}_{4}$ flux in the marshland of the Sanjiang Plain are described in Table 3 and Fig. 5, respectively. A linear increase of $1.3 \mathrm{~kg} \mathrm{ha}^{-1} \mathrm{yr}^{-1}$ was found with respect to the impact of the air temperature on the $\mathrm{CH}_{4}$ flux over the past 6 decades (Fig. 5a). The negative impact on the $\mathrm{CH}_{4}$ flux became lower, whereas significant positive impact on the $\mathrm{CH}_{4}$ flux has occurred since the 1990s (Table 3). Relative to the mean of the 1950s, the warming-induced increase in the area-weighted $\mathrm{CH}_{4}$ flux averaged $19 \mathrm{~kg} \mathrm{ha}^{-1} \mathrm{yr}^{-1}$ over the last two decades.

The annual impact of precipitation on the area-weighted $\mathrm{CH}_{4}$ flux shows obvious interannual variation (Fig. 5b). It contributed a reduction of $\sim 1.5 \mathrm{~kg} \mathrm{ha}^{-1} \mathrm{yr}^{-1}$ to the areaweighted $\mathrm{CH}_{4}$ flux, although this was not statistically significant $(P>0.2)$ (Fig. 5b). This reduction was almost equal to the increase in the area-weighted $\mathrm{CH}_{4}$ flux due to the air temperature (Fig. 5a). Lower precipitation in the 1970s $(462 \mathrm{~mm})$ and $2000 \mathrm{~s}(486 \mathrm{~mm})$ (Fig. $4 \mathrm{~b}$ ) caused the mean annual areaweighted $\mathrm{CH}_{4}$ flux to decrease by $\sim 20 \%$ relative to the 1950s (Table 3). Among the investigated climatic factors, 

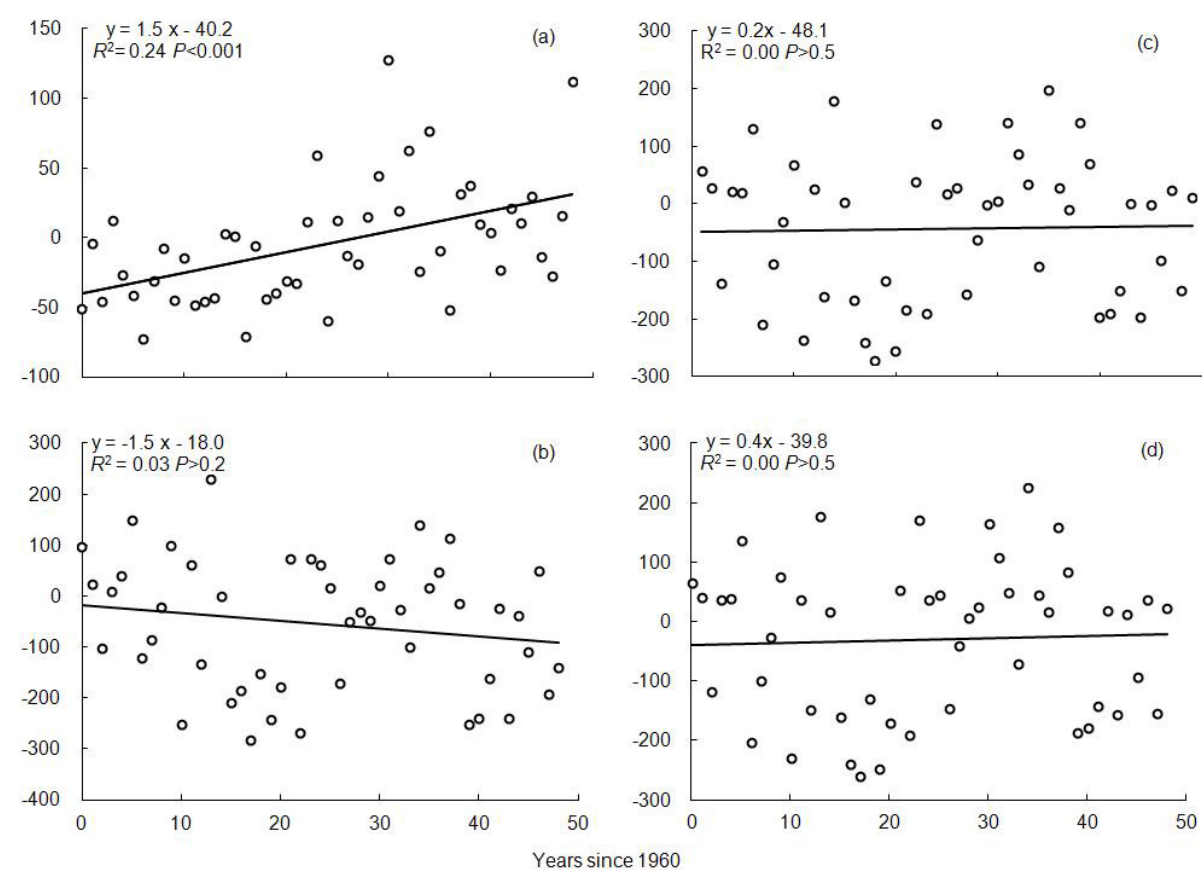

Fig. 5. Impact of air temperature (a), precipitation (b), air temperature and precipitation (c), air temperature, precipitation and net radiation (d) on area-weighted $\mathrm{CH}_{4}$ flux. Estimated $I F_{\mathrm{CF}}^{i}$ by Eq. (4).

precipitation was the main contributor to the reduction of the area-weighted $\mathrm{CH}_{4}$ flux. We estimated that the relatively lower amount of precipitation over the period of 1960-2009 (averaging $47 \mathrm{~mm} \mathrm{yr}^{-1}$ lower than in the 1950s) contributed $\sim 91 \%$ of the reduction in the area-weighted $\mathrm{CH}_{4}$ flux among the climatic factors. This contribution of $91 \%$ was calculated using the equation $\frac{\overline{I F_{P}^{1950 \sim 2009}}}{\overline{I F_{P}^{1950 \sim 2009}}+\overline{I F_{T}^{1950 \sim 2009}}}$, where $\overline{I F_{P}^{1950 \sim 2009}}$ and $\overline{I F_{T}^{1950 \sim 2009}}\left(\mathrm{~kg} \mathrm{ha}^{-1} \mathrm{yr}^{-1}\right)$ (Eq. 5) represented the average impact of precipitation and air temperature on the areaweighted $\mathrm{CH}_{4}$ flux from 1950-2009.

According to this analysis, although the air temperature increased continuously from the 1950 s to the 1980 s, it did not enhance the area-weighted $\mathrm{CH}_{4}$ flux (Table 3). The reason was that the air temperature mainly increased during the growing season (April to October), rather than in winter (November to March), which reduced the number of days from germination to the occurrence of maximum aboveground biomass. An obvious rising trend was detected in the mean temperature of the growing season, which increased at a rate of $2.2^{\circ}$ per decade (linear trend with $P<0.05$ ) from 1950 to 1979 , whereas no trend was found in winter temperatures (linear trend with $P>0.2$ ) during the same period. In northeast China, the required values of GDD are $50^{\circ} \mathrm{d}$ and $2000^{\circ} \mathrm{d}$ for plant germination and for approaching the maximum value, respectively ( $\mathrm{Li}$ et al., 2010). The variation in temperature resulted in a decrease in the length of the days from germination to the occurrence of maximum aboveground biomass at a rate of 2.1 days per decade (lin- ear trend with $P<0.05$ ). According to the logistic equation that was used to calculate the daily aboveground biomass in

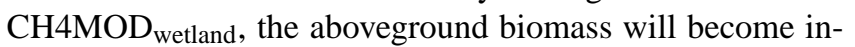
finitely close to the input maximum value as GDD reaches $2000^{\circ} \mathrm{d}$. The greater the number of days between germination and the occurrence of the maximum value, the closer the actual maximum aboveground biomass becomes to the input value. Therefore, the decrease in the number of days from germination to the maximum value resulted in a reduction of the actual maximum aboveground biomass value and, furthermore, decreased the maximum $\mathrm{CH}_{4}$ flux value.

However, the positive impact of the air temperature on the area-weighted $\mathrm{CH}_{4}$ flux during the last 60 years may have been underestimated to some extent in this study. Due to the lack of biomass data in the study area for the last 60 years, we simply assumed that the input maximum aboveground biomass was a constant value from 1950 to 2009. However, increasing air temperature and the $\mathrm{CO}_{2}$ fertilization may promote plant growth over a long period. Therefore, the positive effect of climate warming on the $\mathrm{CH}_{4}$ flux may have been underestimated to some extent. Additionally, the snowmelt process was not considered in the empirical water table model, and the resulting size and melt dates of the snow pack under higher winter temperatures may lead to earlier and larger rises in the water table, which, coupled with higher spring temperatures, could lengthen the duration of substantial $\mathrm{CH}_{4}$ emissions as well as increase $\mathrm{CH}_{4}$ emissions. 


\subsection{Projected impact of climate change on $\mathrm{CH}_{4}$ fluxes by 2100}

\subsubsection{Projected climate change in the RCP scenarios}

The climate projected by FGOALS shows a trend of becoming warmer and wetter in the RCP scenarios. The annual mean precipitation will increase in the range of $9 \%$ to $12 \%$ (46 and $63 \mathrm{~mm}$ ) in the 2030s, $7 \%$ to $17 \%(38$ and $90 \mathrm{~mm}$ ) in the $2050 \mathrm{~s}$, and $12 \%$ to $24 \%$ (62 and $122 \mathrm{~mm}$ ) in the $2080 \mathrm{~s}$ relative to 1961-1990 (Table 4). No significant trend in precipitation was observed within the period from 2010-2100 in the RCP scenarios (Fig. H1).

The annual mean area-weighted air temperature will increase by $49 \%\left(1.5^{\circ} \mathrm{yr}^{-1}\right), 96 \%\left(2.9^{\circ} \mathrm{yr}^{-1}\right), 150 \%$ $\left(4.6^{\circ} \mathrm{yr}^{-1}\right)$ and $238 \%\left(7.3^{\circ} \mathrm{yr}^{-1}\right)$ by the 2080 s relative to 1961-1990 in RCP 2.6, RCP 4.5, RCP 6.0 and RCP 8.5, respectively (Table 4). In RCP 2.6 scenario, the increase of mean annual area-weighted air temperature shows a decreased trend with a rate of. $0.1^{\circ}$ per decade $(P<0.1)$ (Fig. H1a), corresponding to the trend of radiative forcing (Moss et al., 2008). Under the "high pathway" (RCP 8.5) scenario, the projected change in the air temperature from 2010-2100 relative to 1961-1990 shows an obvious linear increase of $0.7^{\circ}$ per decade $(P<0.001)$ (Fig. H1d). There is also an increasing trend in the projected change in the air temperature in the RCP 6.0 scenario, with a rate of $0.2^{\circ}$ per decade $(P<0.001)$ (Fig. H1c).

\subsubsection{Impact of projected climate change on $\mathrm{CH}_{4}$ fluxes by 2100}

The projected area-weighted $\mathrm{CH}_{4}$ fluxes are expected to be increased in the future due to rising air temperature and precipitation (Table 4). In the "near term" - the 2030s (Moss et al., 2008), the differences between the increases of the area-weighted $\mathrm{CH}_{4}$ fluxes in the four RCP scenarios are inconspicuous (Table 4). However, in the "long term" - the 2080s (Moss et al., 2008), the increase in the area-weighted $\mathrm{CH}_{4}$ flux is obviously higher under RCP 8.5 than the other RCP scenarios (Table 4). As the "high pathway" scenario, the RCP 8.5 scenario predicts that the area-weighted $\mathrm{CH}_{4}$ flux will increase by $36 \%$ in the 2030 s, $80 \%$ in the 2050 s and $95 \%$ in the 2080s compared with 1961-1990 (Table 4). In the RCP 6.0 scenario, the area-weighted $\mathrm{CH}_{4}$ flux will increase by $50 \%$ in the 2030 s and 2050 s and by $78 \%$ in the 2080 s (Table 4). Linear trends in the increase of $\mathrm{CH}_{4}$ fluxes from 2010-2100 relative to 1961-1990 are shown in the RCP 6.0 and RCP 8.5 scenarios with rates of $23 \mathrm{~kg} \mathrm{ha}^{-1} \mathrm{yr}^{-1}$ and $48 \mathrm{~kg} \mathrm{ha}^{-1} \mathrm{yr}^{-1}$, respectively (Fig. 6c and d), which is consistent to the trend of the air temperature (Fig. H1). However, there is no significant trend of the increase of area-weighted $\mathrm{CH}_{4}$ fluxes in RCP 2.6 and RCP $4.5(P>0.2)$ (Fig. 6a and b). In the RCP 4.5 scenario, the increase of the area-weighted $\mathrm{CH}_{4}$ flux is stabilized during the 21st century (Table 4 and
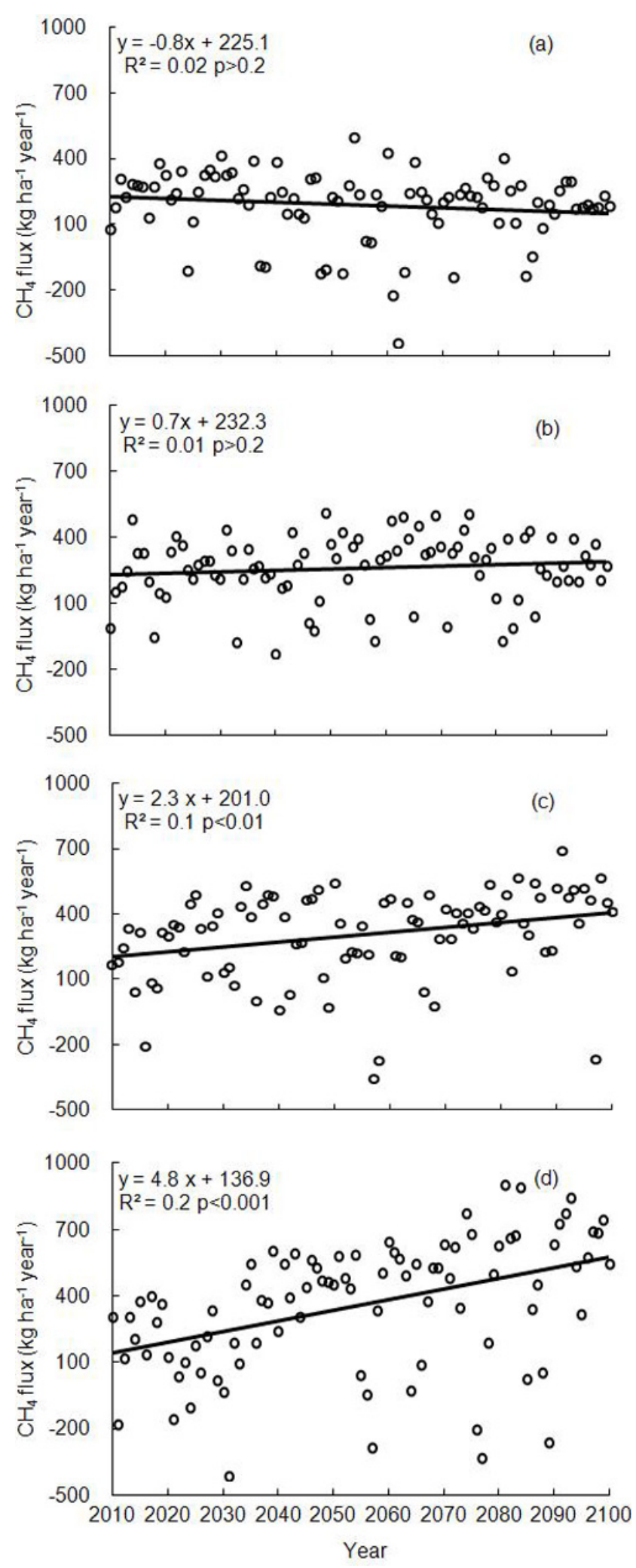

Fig. 6. Projected change of $\mathrm{CH}_{4}$ fluxes relative to 1961-1990 on the Sanjiang Plain for RCP 2.6 (a), RCP 4.5 (b), RCP 6.0 (c) and RCP 8.5 (d). 
Table 4. Projected increases in area-weighted $\mathrm{CH}_{4}$ flux relative to 1961-1990.

\begin{tabular}{|c|c|c|c|c|c|c|c|c|c|c|c|c|}
\hline \multirow{2}{*}{ Decade } & \multicolumn{3}{|c|}{ RCP2.6 } & \multicolumn{3}{|c|}{$\mathrm{RCP} 4.5$} & \multicolumn{3}{|c|}{ RCP6.0 } & \multicolumn{3}{|c|}{ RCP8.5 } \\
\hline & $P^{\mathrm{a}}$ & $T^{\mathrm{b}}$ & $\mathrm{CH}_{4}^{\mathrm{c}}$ & $P$ & $T$ & $\mathrm{CH}_{4}$ & $P$ & $T$ & $\mathrm{CH}_{4}$ & $P$ & $T$ & $\mathrm{CH}_{4}$ \\
\hline $2030 \mathrm{~s}$ & $10 \%$ & $83 \%$ & $46 \%$ & $11 \%$ & $86 \%$ & $45 \%$ & $12 \%$ & $113 \%$ & $50 \%$ & $9 \%$ & $96 \%$ & $36 \%$ \\
\hline $2050 \mathrm{~s}$ & $7 \%$ & $70 \%$ & $27 \%$ & $14 \%$ & $124 \%$ & $57 \%$ & $10 \%$ & $127 \%$ & $50 \%$ & $17 \%$ & $170 \%$ & $80 \%$ \\
\hline $2080 \mathrm{~s}$ & $12 \%$ & $49 \%$ & $36 \%$ & $16 \%$ & $96 \%$ & $52 \%$ & $24 \%$ & $150 \%$ & $78 \%$ & $17 \%$ & $238 \%$ & $95 \%$ \\
\hline
\end{tabular}

${ }^{a}$ Increase in precipitation relative to the baseline of 1961-1990 (515 mm).

${ }^{\mathrm{b}}$ Increase in temperature relative to the baseline of 1961-1990 (3.07 $\left.{ }^{\circ}\right)$.

${ }^{\mathrm{c}}$ Increase in the simulated area-weighted $\mathrm{CH}_{4}$ flux relative to the baseline of $1961-1990\left(513 \mathrm{~kg} \mathrm{ha}^{-1} \mathrm{yr}^{-1}\right)$.

Fig. 6b). In the RCP 2.6, the increase in the area-weighted $\mathrm{CH}_{4}$ flux first reaches $46 \%$ in the 2030s and then declines in the 2050s and 2080s in the RCP 2.6 scenario (Table 4).

The projected area-weighted $\mathrm{CH}_{4}$ fluxes in the four RCP scenarios show obvious interannual variation (Fig. 6) due to the yearly fluctuation of precipitation (Fig. H1). The extreme high and low values of the area-weighted $\mathrm{CH}_{4}$ fluxes are mainly attributed to the extreme high and low area-weighted precipitation, respectively. For example, in the RCP 2.6 scenario, the decreases of the area-weighted precipitation are 215 and $213 \mathrm{~mm}$ in 2061 and 2062, respectively (Fig. H1a). Correspondingly, the decrease in area-weighted $\mathrm{CH}_{4}$ fluxes are 226.8 and $443.4 \mathrm{~kg} \mathrm{ha}^{-1} \mathrm{yr}^{-1}$ relative to the average 1961-1990 in 2061 and 2062, respectively (Fig. 6a). The increase of the area-weighted precipitation is $510.4 \mathrm{~mm}$ in 2033 in RCP 6.0 (Fig. H1c). Correspondingly, the increase in area-weighted $\mathrm{CH}_{4}$ flux is $437 \mathrm{~kg} \mathrm{ha}^{-1} \mathrm{yr}^{-1}$ relative to the average 1961-1990 in 2033 (Fig. 6c).

Using a modeling approach, Zhuang et al. (2006) projected that $\mathrm{CH}_{4}$ emissions from the wetlands in northern high latitudes would more than double over the century in a scenario of projected atmospheric $\mathrm{CO}_{2}$ mole fraction of approximately $1152 \mathrm{ppm}$ by 2100 . In the present study, the projected $\mathrm{CH}_{4}$ flux will be $\sim 2.1$ times over the century, from $505 \mathrm{~kg} \mathrm{ha}^{-1} \mathrm{yr}^{-1}$ in the 2000 s to $1060 \mathrm{~kg} \mathrm{ha}^{-1} \mathrm{yr}^{-1}$ in 2100 , in the RCP 8.5 scenario of projected $\mathrm{CO}_{2}$ concentrations of $1370 \mathrm{ppm}$. This increase is close to the increment reported by Zhuang et al. (2006). In the doubled $\mathrm{CO}_{2}$ scenario ( $\sim 700 \mathrm{ppm}$ ), increases of $56 \%$ (Christensen and Cox, 1995) and $110 \%$ (Shindell et al., 2004) have been estimated for the $\mathrm{CH}_{4}$ flux in the northern high latitude region. The doubled $\mathrm{CO}_{2}$ scenario is similar to the range between the RCP 6.0 scenario and RCP 8.5 scenario $(650 \mathrm{ppm}-850 \mathrm{ppm}$, supplementary material D). Our results show increases of $56 \%$ (from $505 \mathrm{~kg} \mathrm{ha}^{-1} \mathrm{yr}^{-1}$ in the 2000s to $790 \mathrm{~kg} \mathrm{ha}^{-1} \mathrm{yr}^{-1}$ in 2100) and $84 \%$ (from $505 \mathrm{~kg} \mathrm{ha}^{-1} \mathrm{yr}^{-1}$ in the $2000 \mathrm{~s}$ to $930 \mathrm{~kg} \mathrm{ha}^{-1} \mathrm{yr}^{-1}$ in 2100) under the RCP 4.5 scenario and RCP 6.0 scenario, respectively. These results are close to that of Christensen and Cox (1995), but lower than the estimate of Shindell et al. (2004). Thus, there is qualitative agreement among the existing studies that climate change can greatly enhance methane emissions from wetlands in the future, but the magnitude is uncertain. If the model considers the promoting effects of climate warming on snowmelt and the elevated $\mathrm{CO}_{2}$ on plant growth, the projected $\mathrm{CH}_{4}$ flux in the 21st century may be higher than the estimates presented here.

In this study, we estimated the area-weighted $\mathrm{CH}_{4}$ flux from the marshland in the projected climate scenarios from 2010 to 2100 . The regional $\mathrm{CH}_{4}$ emissions from the marshland of the Sanjiang Plain depend on the $\mathrm{CH}_{4}$ flux and the marshland area. However, it is hard to estimate the change of marshland area in the future. This is because both of the climate change and the government's policy will influence the development of the marshland area in the future. During the past 60 years, the marshland area on the Sanjiang Plain decreased by $3.2 \mathrm{M}$ ha (Fig. 2). This decrease was mainly due to intensive cultivation. There may not be intensive marshland cultivation in the future. The wetland conservation policy might increase the marshland area. However, the increased air temperature will cause a marshland loss by increasing the evapotranspiration. Simulating the development of marshland is important in future work.

\section{Conclusions}

An estimated cumulative reduction of $\sim 36 \mathrm{Tg}(24-57 \mathrm{Tg})$ in regional $\mathrm{CH}_{4}$ emissions from the Sanjiang Plain of northeast China occurred from 1960 to 2009 relative to the 1950s. Approximately $86 \%$ of the reduction was attributed to extensive conversion of marshland to cropland over a total area of 3.2 M ha. Relatively low precipitation also contributed to the reduction in $\mathrm{CH}_{4}$ emissions, while an increase in temperature obviously enhanced $\mathrm{CH}_{4}$ emissions over the last two decades. In the RCP scenarios, it is predicted that climate change will greatly enhance methane flux from marshland on the Sanjiang Plain in the future.

\section{Supplementary material related to this article is available online at: http://www.biogeosciences.net/9/ 5199/2012/bg-9-5199-2012-supplement.pdf.}


Acknowledgements. This work was supported by the National Natural Science Foundation of China (Grant No. 31000234, 41075107 and 41021004), the Chinese Academy of Sciences (CAS) strategic pilot technology special funds (Grant No. XDA05020204) and the External Cooperation Program of the Chinese Academy of Sciences (Grant No. GJHZ1213). We are grateful to the members at the Sanjiang Wetland Experimental Station, the Chinese Academy of Sciences for their contribution to the measurements of $\mathrm{CH}_{4}$ emission, water table position and the plant biomass. We would also like to thank the National Meteorological Information Center of the China Meteorological Administration and the State Key Laboratory of Numerical Modeling for Atmospheric Sciences and Geophysical Fluid Dynamics of the Institute of Atmospheric Physics, Chinese Academy of Sciences for providing data.

Edited by: P. Stoy

\section{References}

Allen, R. G., Pereira, L. S., Raes, D., and Smith, M.: Crop evapotranspiration: Guidelines for computing crop water requirements, in: Irrigation and Drainage Paper No. 56, FAO, Rome, Italy, available at: http://www.fao.org/docrep/X0490E/ X0490E00.htm, 1998.

An, S. Q., Li, H. B., Guan, B. H., Zhou, C. F., Wang, Z. S., Deng, Z. F., Zhi, Y. B., Liu, Y. L., Xu, C., Fang, S. B., Jiang, J. H., and Li, H. L.: China's natural wetlands: past problems, current status, and future challenges, Ambio, 36, 335-342, 2007.

Beldring, S., Engen-Skaugen, T., Førland, E. J., and Roald, L. A.: Climate change impacts on hydrological processes in Norway based on two methods for transferring regional climate model results to meteorological station sites, Tellus A, 60, 439-450, 2008.

Bernie, D.: Temperature implications from the IPCC 5th assessment Representative Concentration Pathways (RCP), Work stream 2, Report 11 of the AVOID programme (AV/WS2/D1/R11), available at: www.avoid.uk.net, 2010.

Bertness, M. D.: Peat accumulation and the success of marsh plants, Ecology, 69, 703-713, 1988.

Bridgham, A. D., Megonigal, J. P., Keller, J. K., Bliss, N. B., and Trettin, C.: The carbon balance of North American wetlands, Wetlands, 26, 889-916, 2006.

Boon, P. I., Mitchell, A., and Lee, K.: Effects of wetting and drying on methane emissions from ephemeral floodplain wetlands in southeastern Australia, Hydrobiologia, 357, 73-87, 1997.

Cao, M. K., Gregson, K., and Marshall, S.: Global methane emission from wetlands and its sensitivity to climate change, Atmos. Environ., 32, 3293-3299, 1998.

Charmann, D. J. and Hendon, D.: Long-term changes in soil water tables over the past 4500 years: relationships with climate and north Atlantic atmospheric circulation and sea surface temperature, Clim. Change, 47, 45-59, 2000.

Christensen, T. R. and Cox, P.: Response of methane emission from arctic tundra to climate change: results from a model simulation, Geophys. Res. Lett., 31, L04501, doi:10.1029/2003GL018680, 1995.

Cui, B. S.: $\mathrm{CH}_{4}$ emission from wetland in Sanjiang Plain, Sci. Geogr. Sin., 17, 93-95, 1997 (in Chinese with English abstract).

Cui, B. S., Ma, X. H., and Zhang, M. X.: Regularity and estimation of methane emission from marshland in the Sanjiang Plain,
Chinese Geogra. Sci., 8, 74-84, 1998.

Ding, W. X. and Cai, Z. C.: Methane emission from natural wetlands in China: Summary of years 1995-2004 studies, Pedosphere, 17, 475-486, 2007.

Ding, W. X., Cai, Z. C., Tsuruta, H., and Li, X. P.: Effect of standing water depth on methane emissions from freshwater marshes in northeast China, Atmos. Environ., 36, 5149-5157, 2002.

Ding, W. X., Cai, Z. C., and Wang, D. X.: Preliminary budget of methane emissions from natural wetlands in China, Atmos. Environ., 38, 751-759, 2004.

$\mathrm{Du}, \mathrm{X}$. and Chen, W.: Towards a better understanding of modeling feasibility robustness in engineering design, 1999 ASME design technical conference, Paper No. DAC-8565, Las Vegas, Nevada, September 1999.

Editorial Committee of China's National Assessment Report on Climate Change (Eds.): China's National Assessment Report on Climate Change, Science Press, Beijing, China, 2007 (in Chinese).

Frolking, S., Roulet, N. T., Moore, T. R., Richard, P. J. H., Lavoie, M., and Muller, S. D.: Modeling northern peatland decomposition and peat accumulation, Ecosystems, 4, 479-498, 2001.

Gong, P., Niu, Z. G., Cheng, X., Zhao, K. Y., Zhou, D. M., Guo, J. G., Liang, L., Wang, X. F., Li, D. D., Huang, H. B., Wang, Y., Wang, K., Li, W. N., Wang, X. W., Ying, Q., Yang, Z. Z., Ye, Y. F., Li, Z., Zhuang, D. F., Chi, Y. B., Zhou, H. Z., and Yan, J.: China's wetland change (1990-2000) determined by remote sensing, Sci. China Ser. D-Earth Sci., 53, 1036-1042, doi:10.1007/s11430-010-4002-3, 2010.

Gorham, E., Janssens, J. A., and Glaser, P. H.: Rates of peat accumulation during the postglacial period in 32 sites from Alaska to Newfoundland, with special emphasis on northern Minnesota, Can. J. Bot., 81, 429-438, 2003.

Gedney, N., Cox, P. M., and Huntingford, C.: Climate feedback from wetland methane emissions, Geophys. Res. Lett., 31, L20503, doi:10.1029/2004GL020919, 2004.

Group of Chinese Wetland Resources Development and Environmental Protection: Development history of the Sanjiang Plain, Territ. Nat. Resour. Study, 1, 15-19, 1998 (in Chinese).

Guo, X. L., Lv, X. G., Dai, G. H.: Aboveground biomass dynamics within wetlands along a water level gradient in the Sanjiang Plain, Ecol. Environ., 17, 1739-1742, 2008 (in Chinese with English abstract).

Hao, Q. J.: Effect of land-use change on greenhouse gases emissions in freshwater marshes in the Sanjiang Plain, Ph.D. thesis, Institute of Atmospheric Physics, Chinese Academy of Sciences, Beijing, 205 pp., 2006 (in Chinese with English abstract).

Hao, Q. J., Wang, Y. S., Song, C. C., Liu, G. R., Wang, Y. Y., and Wang, M. X.: Study of $\mathrm{CH}_{4}$ emission from wetlands in Sanjiang Plain, J. Soil Water Conservation, 18, 194-199, 2004 (in Chinese with English abstract).

Hay, L. E., Wilby, R. T., and Leavesley, G. H.: A comparison of delta change and downscaled GCM scenarios for three mountainous basins in the United States, J. Am. Water Resour. As., 36, 387-397, 2000.

Hulme, M., Conway, D., Jones, P. D., Jiang, T., Barrow, E. M., and Turney, C.: Construction of a 1961-1990 European climatology for climate change modelling and impact applications, Int. J. Climatol., 15, 1333-1363, 1995.

He, C. Q.: The biological process of Carex lasiocarpa wetland in Sanjiang Plain: I. The growing law of aboveground biomass, 
Grassland China, 23, 11-16, 2001 (in Chinese with English abstract).

Heilongjiang Provencal Bureau of Statistics (Eds.): Heilongjiang Provencal Bureau of Statistics, 2010, China Statistical Press, Beijing, China, 2010 (in Chinese).

Huang, Y., Zhang, W., Zheng, X. H., Li, J., and Yu, Y. Q.: Modeling methane emission from rice paddies with various agricultural practices, J. Geophys. Res., 109, D08113, doi:10.1029/2003JD004401, 2004.

Huang, Y., Zhang, W., Zheng, X. H., Han, S. H., and Yu, Y. Q.: Estimates of methane emissions from Chinese rice paddies by linking a model to GIS database, Acta Ecological Sinca, 26, 980988, 2006.

Huang, Y., Sun, W., Zhang, W., Yu, Y., Su, Y., and Song, C.: Marshland conversion to cropland in northeast China from 1950 to 2000 reduced the greenhouse effect, Glob. Change Biol., 16, 680-695, 2010.

IPCC: Climate Change 2007: The Physical Science Basis, Summary for Policymakers, Contribution of Working Group I to the Fourth Assessment Report of the Intergovernmental Panel on Climate Change, Intergovernmental Panel on Climate Change, Paris, France, 2007.

Jia, Z. J., Zhang, W., Huang, Y., Song, C. C., and Zhao, X. S.: Effects of marshland reclamation on evapotranspiration in the Sanjiang Plain, Environ. Sci., 31, 833-842, 2010 (in Chinese with English abstract).

King, A. W., Johnson, A. R., and O'Neill, R. V.: Transmutation and functional representation of heterogeneous landscapes, Landscape Ecol., 5, 239-253, 1991.

Li, C. S., Cui, J. B., Sun, G., and Trettin, C.: Modeling impacts of management on carbon sequestration and trace gas emissions in forested wetland ecosystems, Environ. Manage., 33, 176-186, 2004.

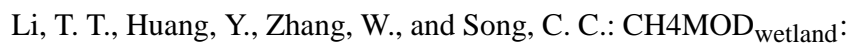
A biogeophysical model for simulating $\mathrm{CH}_{4}$ emissions from natural wetland, Ecol. Model., 221, 666-680, 2010.

Liu, X. T. and Ma, X. H.: Influence of large scale reclamation on natural environment and regional environmental protection in the Sanjiang Plain, Sci. Geogr. Sin., 20, 14-19, 2000 (in Chinese with English abstract).

Ma, Z.: Protection, development and economic evaluation of the Sanjiang Plain, Ph.D. thesis, Renmin University of China, Beijing, 1999 (in Chinese with English abstract).

Ma, X. H., Lu, X. G., Yang, Q., and Yan, M. H.: Carbon cycle of a marsh in Sanjiang Plain, Scientia Geographica Sin., 16, 323-330, 1996 (in Chinese English abstract).

Mitsch, J. W. and Gosselink, J. G.: Wetlands, 4th edn, John Wiley and Sons Inc, Hoboken, NJ, 2007.

Moss, R., Babiker, M., Brinkman, S., Calvo, E., Carter, T., Edmonds, J., Elgizouli, I., Emori, S., Erda, L., Hibbard, K., Jones, R., Kainuma, M., Kelleher, J., Lamarque, J. F., Manning, M., Matthews, B., Meehl, J., Meyer, L., Mitchell, J., Nakicenovic, N., O’Neill, B., Pichs, R., Riahi, K., Rose, S., Runci, P., Stouffer, R., van Vuuren, D., Weyant, J., Wilbanks, T., van Ypersele, J. P., and Zurek, M.: Towards new scenarios for analysis of emissions, climate change, impacts, and response strategies, Technical summary, Intergovernmental Panel on Climate Change, Geneva, 25 pp., 2008.
Ni, H. W.: Study on the biomass of above-ground organs and layer structure of Deyeuxia angustifolia in typical mdeadow on Sanjiang Plain, Bull. Bot. Res., 16, 356-362, 1996 (in Chinese with English abstract).

Ning, J., Zhang, S. W., Li, Y., and Wang, L.: Analysis on wetland shrinking characteristics and its cause in Heilongjiang province for the last 50 years, J. Nat. Resour., 23, 79-86, 2008 (in Chinese with English abstract).

Ogle, S., Breidt, F., Eve, M., and Paustian, K: Uncertainty in estimating land use and management impacts on soil organic carbon storage for US agricultural lands between 1982 and 1997, Global Change Biol., 9, 1521-1542, 2003.

Ogle, S., Breidt, F., Easter, M., Williams, S., Killian, K., and Paustian, K.: Scale and uncertainty in modeled soil organic carbon stock changes for US croplands using a process-based model, Global Change Biol., 16, 810-822, 2010.

Priestley, C. H. B. and Taylor, R. J.: On the assessment of surface heat flux and evaporation using large-scale parameters, Mon Weather Rev., 100, 81-92, 1972.

Prudhomme, C., Reynard, N., and Crooks, S.: Downscaling of global climate models for flood frequency analysis: where are we now?, Hydrol. Processes, 16, 1137-1150, 2002.

Ramsar Convention Secretariat (Eds.): Ramsar Handbook for the Wise Use of Wetlands, 2nd Edition, Handbook 10, Wetland Inventory: A Ramsar Framework for Wetland Inventory, Ramsar secretariat, Gland, Switzerland, 2004.

Revenga, C., Brunner, J., Henninger, N., Kassem, K., and Payne, R. (Eds.): Pilot Analysis of Global Ecosystems: Freshwater Systems, World Resources Institute, Washington, D.C., 65 pp, 2000.

Shindell, D. T., Walter, B. P., and Faluvegi, G.: Impacts of climate change on methane emissions from wetlands, Geophys. Res. Lett., 31, L21202, doi:10.1029/2004GL021009, 2004.

Shuttleworth, W. J.: Evaporation, in: Handbook of Hydrology 4.14.53, edited by: Maidment, D. R., McGraw-Hill, New York, USA, 1992.

Song, C. C., Zhang, J. B., Wang, Y. Y., Wang, Y. S., and Zhao, Z. C.: Emission of $\mathrm{CO}_{2}, \mathrm{CH}_{4}$ and $\mathrm{N}_{2} \mathrm{O}$ from freshwater marsh in northeast of China, J. Environ. Manage., 40, 6879-6885, 2007.

Song, C. C., Xu, X. F., Tian, H. Q., and Wang, Y. Y.: Ecosystematmosphere exchange of $\mathrm{CH}_{4}$ and $\mathrm{N}_{2} \mathrm{O}$ and ecosystem respiration in wetlands in the Sanjiang Plain, Northeastern China, Glob. Change Biol., 15, 692-705, 2009.

Strack, M., Waddington, M., Turetsky, M., Roulet, N. T., and Byrne, K. A.: Northern peatlands, greenhouse gas exchange and climate change, in: Peatlands and climate change, Chapter 2, edited by: Strack, M., International Peat Society, Vapaudenkatu Jyväskylä, Finland, 44-69, 2008.

$\mathrm{Su}$, Y. H. and Zhang, W.: Building up annual series of cropland acreage in Sanjiang Plain in the last 50 years, Geogr. GeoInformation Science, 24, 72-75, 2008 (in Chinese with English abstract).

Sun, L. and Song, C. C.: Evapotranspiration from a freshwater marsh in the Sanjiang Plain, Northeast China, J. Hydrol., 352, 202-210, 2008.

Updegraff, K., Bridgham, S. D., Pastor, J., Weishampel, P., and Harth, C.: Response of $\mathrm{CO}_{2}$ and $\mathrm{CH}_{4}$ emissions from peatlands to warming and water table manipulation, Ecol. Appl., 11, 311326, 2001. 
van Bodegom, P. M., Leffelaar, P. A., Stams, A. J. M., and Wassmann, R.: Modeling methane emissions from rice fields: Variability, uncertainty, and sensitivity analysis of processes involved, Nutr. Cycl. in Agroecosys., 58, 231-248, 2000.

Vepraskas, M. J. and Caldwell, P. V.: Interpreting morphological features in wetland soils with a hydrological model, Catena, 73, 153-165, 2008.

Wang, A. H., Zhang, S. Q., and He, Y. F.: Study on dynamic change of mire in Sanjiang Plain based on RS and GIS, Sci. Geogr. Sin., 22, 636-640, 2002 (in Chinese with English abstract).

Wang, A. H., Zhang, S. Q., and Zhang, B.: A study on the change of spatial pattern of wetland in the Sanjiang Plain, Acta Ecological Sinca, 23, 237-243, 2003a (in Chinese with English abstract).

Wang, D. X., Ding, W. X., Wang, Y. Y.: Influence of major environmental factors on difference of methane emission from Zoige plateau and Sanjiang Plain wetland, Wetland Sci., 1, 63-67, 2003b (in Chinese with English abstract).

Wang, Y. J., Wang, J. X., Lin, J., Zhou, R. C., Wang, C. Z.: Study on the above-ground biomass of four species of herbaceous plant on the Sanjiang Plain, Territ. Nat. Resour. Stud., 2, 73-76, 1993 (in Chinese).

Wang, Z. M., Zhang, B., Zhang, S. Q., Li, X. Y., Liu, D. W., Song, C. C., Li, J. P., Li, F., and Duan, H. T.: Changes of land use and of ecosystem service values in Sanjiang Plain, northeast China, Environ. Monit. Assess., 112, 69-91, 2006.

Wang, Z. M., Song, K. S., Liu, D. W., Zhang, B., Zhang, S. Q., Li, F., Ren, C. Y., Jin, C., Yang, T., and Zhang, C. H.: Process of land conversion from marshland into cropland in the Sanjiang Plain during 1954-2009, Wetland Sci., 7, 208-217, 2009 (in Chinese with English abstract).

Wilby, R. L., Charles, S. P., Zorita, E., Timbal, B., Whetton, P., and Mearns, L. O.: Guidelines for use of climate scenarios developed from statistical downscaling methods, Supporting material of the Intergovernmental Panel on Climate Change, available from the DDC of IPCC TGCIA, 27, 2004.

Xu, X. F. and Tian, H. Q.: Methane exchange between the marshland and the atmosphere over China during 1949-2008, Glob. Biogeochem. Cy., 26, GB2006, doi:10.1029/2010GB003946, 2012.

Yang, J. S., Liu, J. S., Wang, J. D., Yu, J. B., Sun, Z. G., and Li, X. H.: Emissions of $\mathrm{CH}_{4}$ and $\mathrm{N}_{2} \mathrm{O}$ from a wetland in the Sanjiang Plain, J. Plant Ecol., 30, 432-440, 2006a (in Chinese with English abstract).

Yang, W. Y., Song, C. C., Zhang, J. B.: Dynamics of methane emissions from a freshwater marsh of northeast China, Sci. Total Environ., 371, 286-292, 2006b.

Yang, Y., Wang, S., He, T., Tian, K., and Yang, B.: Study on plant biomass and its seasonal dynamics of typical wetland ecosystems in the Sanjiang Plain, Grassland China, 24, 1-7, 2002 (in Chinese with English abstract).

Yu, Y., Yu, R., Zhang, X., and Liu, H.: A flexible coupled oceanatmosphere general circulationmode1, Adv. Atmos. Sci., 19, 169-190, 2002.
Yu, Y., Zhang, X., and Guo, Y.: Global coupled ocean-atmosphere general circulation models in LASG/IAP, Adv. Atmos. Sci., 21, 444-455, 2004.

Zhang, J., Ma, K., and Fu, B.: Wetland loss under the impact of agricultural development in the Sanjiang Plain, NE China, Environ. Monit. Assess., 166, 139-148, 2010.

Zhang, L. H., Song, C. C., Zheng, X. H., Wang, D. X., and Wang, Y. Y.: Effects of nitrogen on the ecosystem respiration, $\mathrm{CH}_{4}$ and $\mathrm{N}_{2} \mathrm{O}$ emissions to the atmosphere from the freshwater marshes in northeast China, Environ. Geol., 52, 529-539, 2007.

Zhang, S. Q., Wang, A. H., Zhang, J. Y., and Zhang, B.: The spatial temporal dynamic characteristics of the marsh in the Sanjiang Plain, J. Geogr. Sci., 13, 201-207, 2003.

Zhang, S. W., Zhang, Y. Z., L, Y., and Chang, L. P.: Spatial and temporal variations in marshlands and its ecological effects, in: Analysis of the spatial and temporal characteristics of landuse and cover in the northeast, Chapter 7, edited by: Zhang, S. W., Zhang, Y. Z., L, Y., and Chang, L. P., Science Press, Beijing, China, 279-312, 2006 (in Chinese).

Zhang, W. J., Xiao, H. A., Tong, C. L., Su, Y. R., Xiang, W. S., Huang, D. Y., Syers, J. K., and Wu, J. S.: Estimating organic carbon storage in temperate wetland profiles in Northeast China, Geoderma, 146, 311-316, 2008.

Zhang, Y., Li, C. S., Trettin, C. C., Li, H., and Sun, G.: An integrated model of soil, hydrology, and vegetation for carbon dynamics in wetland ecosystems, Glob. Biogeochem. Cy., 16, 1061, doi:10.1029/2001GB001838, 2002.

Zhao, C. Y., Ren, G. Y., Zhang, Y. F., and Wang, Y.: Climate change of the northeast China over the past 50 years, J. Arid Land Resour. Environ., 23, 25-30, 2009 (in Chinese with English abstract).

Zhao, X. S., Huang, Y., Jia, Z. J., Liu, H. Z., Song, T., Wang, Y. S., Shi, L. Q., Song, C. C., and Wang, Y. Y.: Effects of the conversion of marshland to cropland on water and energy exchanges in northeastern China, J. Hydrol., 355, 181-191, 2008.

Zhou, D. M., Gong, H. L., Wang, Y. Y., Khan, S., and Zhao, K. Y.: Driving forces for the marsh wetland degradation in the honghe national nature reserve in Sanjiang Plain, northeast China, Environ. Model Assess., 14, 101-111, 2009.

Zhou, W. M., Wang, J. D., and Liu, J. S.: Study on the relation of plant biomass and $\mathrm{CH}_{4}, \mathrm{~N} 2 \mathrm{O}$ emission in the wetland of Sanjiang Plain, Journal of the Graduate School of the Chinese Academy of Sciences, 23, 736-743, 2006 (in Chinese with English abstract).

Zhuang, Q. L., Mellillo, J. M., Sarofim, M. C., Kicklighter, D. W., McGuire, A. D., Felzer, B. S., Sokolov, A., Prinn, R. G., Steudle, P. A., and $\mathrm{Hu}, \mathrm{S}$. M.: $\mathrm{CO}_{2}$ and $\mathrm{CH}_{4}$ exchanges between land ecosystems and the atmosphere in northern high latitudes over the 21st century, Geophys. Res. Lett., 33, L17403, doi:10.1029/2006GL026972, 2006. 